\title{
Assessment of groundwater quality in Kashipur Block, Purulia district, West Bengal
}

\author{
Anindita Kundu' ${ }^{1}$ S. K. $\mathrm{Nag}^{1}$
}

Received: 24 April 2017 / Accepted: 26 January 2018 / Published online: 8 February 2018

(c) The Author(s) 2018. This article is an open access publication

\begin{abstract}
Hydrogeochemical investigation of groundwater resources of Kashipur Block, Purulia district, West Bengal has been carried out to assess the water quality for domestic and irrigation uses. Twenty groundwater samples were collected and analyzed for $\mathrm{pH}$, electrical conductivity, total dissolved solids, hardness, major anions $\left(\mathrm{CO}_{3}{ }^{2-}, \mathrm{HCO}_{3}{ }^{-}, \mathrm{Cl}^{-}, \mathrm{SO}_{4}{ }^{2-}, \mathrm{F}^{-}\right)$and cations $\left(\mathrm{Ca}^{2+}\right.$, $\left.\mathrm{Mg}^{2+}, \mathrm{Fe}^{2+}, \mathrm{Na}^{+}, \mathrm{K}^{+}\right)$. Study results reveal that the groundwater of the area is mostly acidic in nature. The trend amongst average ionic concentrations of cations and anions is $\mathrm{Mg}^{2+}>\mathrm{Ca}^{2+}>\mathrm{Na}^{+}>\mathrm{Fe}^{2+}>\mathrm{K}^{+}$and $\mathrm{Cl}^{-}>\mathrm{HCO}_{3}{ }^{-}>\mathrm{CO}_{3}{ }^{2-}>\mathrm{SO}_{4}{ }^{2-}>\mathrm{F}^{-}$ respectively during the post monsoon whereas the trend for cations and anions are $\mathrm{Mg}^{2+}>\mathrm{Ca}^{2+}>\mathrm{Na}^{+}>\mathrm{K}^{+}>\mathrm{Fe}$ and $\mathrm{Cl}^{-}>\mathrm{HCO}_{3}{ }^{-}>\mathrm{SO}_{4}{ }^{2-}>\mathrm{F}^{-}>\mathrm{CO}_{3}{ }^{-}$in pre monsoon session, respectively. To explore the ionic toxicity of the study area, the derived parameters like sodium adsorption ratio, soluble sodium percentage, residual sodium carbonate, magnesium adsorption ratio, Kelly's ratio and permeability index were calculated. The hydro geochemical data suggest that weathering of rock forming minerals along with secondary contributions from agricultural and anthropogenic sources are mainly controlling the groundwater composition of Kashipur Block, Purulia District. According to piper diagram, water samples of most of the area of the block are fresh water and in some areas sulphate rich throughout the year. All samples are distributed to central rock dominance category. Groundwater chemistry of this block is mainly controlled by the interaction existing between the litho units and the percolating water into the subsurface domain. However, the groundwater quality and suitability of this study area can be termed as good to moderate with a few exceptions which have been encountered on a local scale.
\end{abstract}

Keywords Hydrochemistry $\cdot$ Irrigation suitability $\cdot$ Drinking suitability $\cdot$ Kashipur Block $\cdot$ Purulia district

\section{Introduction}

Water is an elixir of life. It is highly essential for all living beings. Water is not only a vital environmental factor to all form of life, but also it has a great role to play in socioeconomic development of human population (Park 1997). Groundwater is considered as the purest form of water sourced from natural resources. It is usually clear, colorless and remains relatively at constant temperature. Therefore, it is normally superior to surface water in terms of sanitary consideration. Groundwater plays an important role as vital source of drinking water in rural and urban areas of India. According to some estimates, it accounts for nearly $80 \%$ of the rural domestic water needs, and $50 \%$ of the urban

\section{S. K. Nag}

sisirknag@gmail.com

1 Department of Geological Sciences, Jadavpur University, Kolkata 700032, India water needs in India. From quenching thirst, washing, cleaning, use for agriculture to operation of high-power industries, groundwater plays a very vital role. This indispensable resource is a victim of over-exploitation, pollution and exhaustion. Rate of groundwater development and management is not at par with rate of utilization. Presently India is the biggest user of groundwater for agriculture in the world (Shah 2009).

The presence of dissolved minerals coupled with some special characteristics of groundwater as compared to surface water makes it a preferred choice for many purposes (Rajankar et al. 2009; Goel 2000). The chemical quality of groundwater depends on the characteristics of the soil and rock media through which it passes to the groundwater zone of saturation (Raji and Alagbe 1997; Acheampong and Hess 1998; Olayinka et al. 1999; Foster et al. 2000). It is also dependent on the length of time the water remains stored in the ground (residence time) (MacDonald et al. 2002). Various researchers carried out the hydrochemical 
characteristics of groundwater and quality of groundwater in different basins as well in urban areas (Rao et al. 1997; Subramani et al. 2005; Umar et al. 2006; Pandian and Sankar 2007; Raju 2007).

The groundwater quality is as important as its quantity owing to its suitability for various purposes (Schiavo et al. 2006; Subramani et al. 2005). Assessment of hydrochemical quality of groundwater systems is usually based on the availability of a large amount of information concerning groundwater chemistry (Afzali et al. 2014; Naseem et al. 2011; Aghazadeh and Mogaddam 2010; Hossein 2004). Aquifer waters withstand from large-scale contamination. Unlike rivers, the deterioration is commonly irreversible. Rate of groundwater renewal is absolutely slow in analogy to that of surface water. Since the movement of water in aquifers is absolutely slow, the pollutants what is coming get time to accumulate. Hence the amount of safe and clean water is comparatively diminishing. The hydrochemistry of groundwater depends on source of groundwater itself, ion-exchange process, interaction with aquifer material (Mercado 1985) and reaction of the water with the rocks and sediments through which they flow (Garrels and MacKenzie 1967). There are various physicochemical parameters which play a vital role regarding the quality of groundwater for consumption and irrigation purposes. If the concentration of any parameter is above the prescribed limit (according to WHO and BIS specifications) there can be serious health issues. Several workers have assessed the groundwater quality and its suitability for drinking and irrigation purposes (Al-Futaisi et al. 2007; Jalali 2006; Pritchard et al. 2008; Rivers et al. 1996; Nag and Lahiri 2012; Nag and Ghosh 2013; Nag 2014; Nag and Das 2017; Tiwari 2011). Aghazadeh and Mogaddam (2010) assessed the groundwater quality and its suitability in the Oshnavieh area, Iran based on physical and chemical parameters. Kaka et al. (2011) evaluated the hydrochemistry and groundwater suitability for irrigation and drinking purposes in the southeastern Volta river basin of Ghana. Tripathy and Panigrahy (1999) carried out detailed hydrochemical analysis of water samples from the coastal tract of south Orissa to assess the quality of groundwater in the region. Ground water quality zonation was done in Nalgonda district using GIS techniques by Brindha and Elango (2012). Assessment of quality of this vital resource and monitoring of its different parameters is essential for particularly water from those sources which serve as drinking water sources (Reddi et al. 1993). Groundwater quality has been deteriorating over the last few decades due to massive rise in rate of industrialization and population (Pichaiah et al. 2013; Vasanthavigar et al. 2010).

The sources of water supply to the area are through handdug wells, boreholes and surface water. These sources of water supply especially from the hand-dug wells and surface water are polluted due to human activities. These activities includes the use of pit latrines by most resident and indiscriminate dumping of house hold solid waste which contribute to the contamination of water from different sources in the study area. Most of the hand-dug wells are shallow and often left open that renders the well susceptible to contamination by surface water during heavy rainstorms (precipitation) as well as human activities. This unfortunate situation has led to the prevalence of water borne diseases. It is against this background that the physico-chemical assessment of shallow groundwater of Kashipur area in Purulia District is being carried out. Based on the study recommendation that will serve, as useful guide in arresting the situation will be made.

This block has semi-arid climate and people are mostly dependent on groundwater for irrigation. To achieve the above objective, different indices for irrigation uses such as sodium adsorption ratio (SAR), soluble sodium percentage (SSP), residual sodium carbonate (RSC), magnesium adsorption ratio (MAR), Kelly's ratio (KR) and permeability index (PI) were calculated from standard equations and employed to assess the suitability of groundwater for irrigation purposes in the study area. Attempts have also been made to graphical representation for various water quality parameters which aids policy makers in taking rapid decision on rational use and further exploitation of this resource. Since there has been no previous study on groundwater quality of this block, this study also aims at exhaustively discussing the groundwater quality of Kashipur block.

\section{Study area}

Kashipur (community development block) is an administrative division in Raghunathpur subdivision of Purulia district in West Bengal, India (Fig. 1). It is located on the western edge of the district, bordering on Jharkhand. The latitudinal and longitudinal extents are $23.18^{\circ} \mathrm{N}-23.31^{\circ} \mathrm{N}$ and $86.34^{\circ} \mathrm{E}-86.52^{\circ} \mathrm{E}$. It has an area of $430 \mathrm{~km}^{2}$. It has an average elevation of $190 \mathrm{~m}(620 \mathrm{ft})$. The block experiences hot and humid tropical climate. Summer begins from mid-March and continues till June with scorching heat and temperatures soaring up to $48{ }^{\circ} \mathrm{C}$. South west monsoon laden winds bring rains from June to October. Annual rainfall varies from 1100 to $1500 \mathrm{~mm}$. Dry, bitter winters are experienced from November to February with temperatures falling to $4-5^{\circ} \mathrm{C}$. It is a drought prone block.

The entire block has an undulating topography. The western and south western parts are more rugged compared to the eastern part. The principal rivers originating in Purulia district are the Dwarakeswar, the Kangsabati and the Silabati and there are also a large number of rivulets. In this block, the Dwarakeswar and its rivulets Dudhbheria, Darobhara, Futuari, Beko are the principal river system. Regionally the drainage pattern of this area 


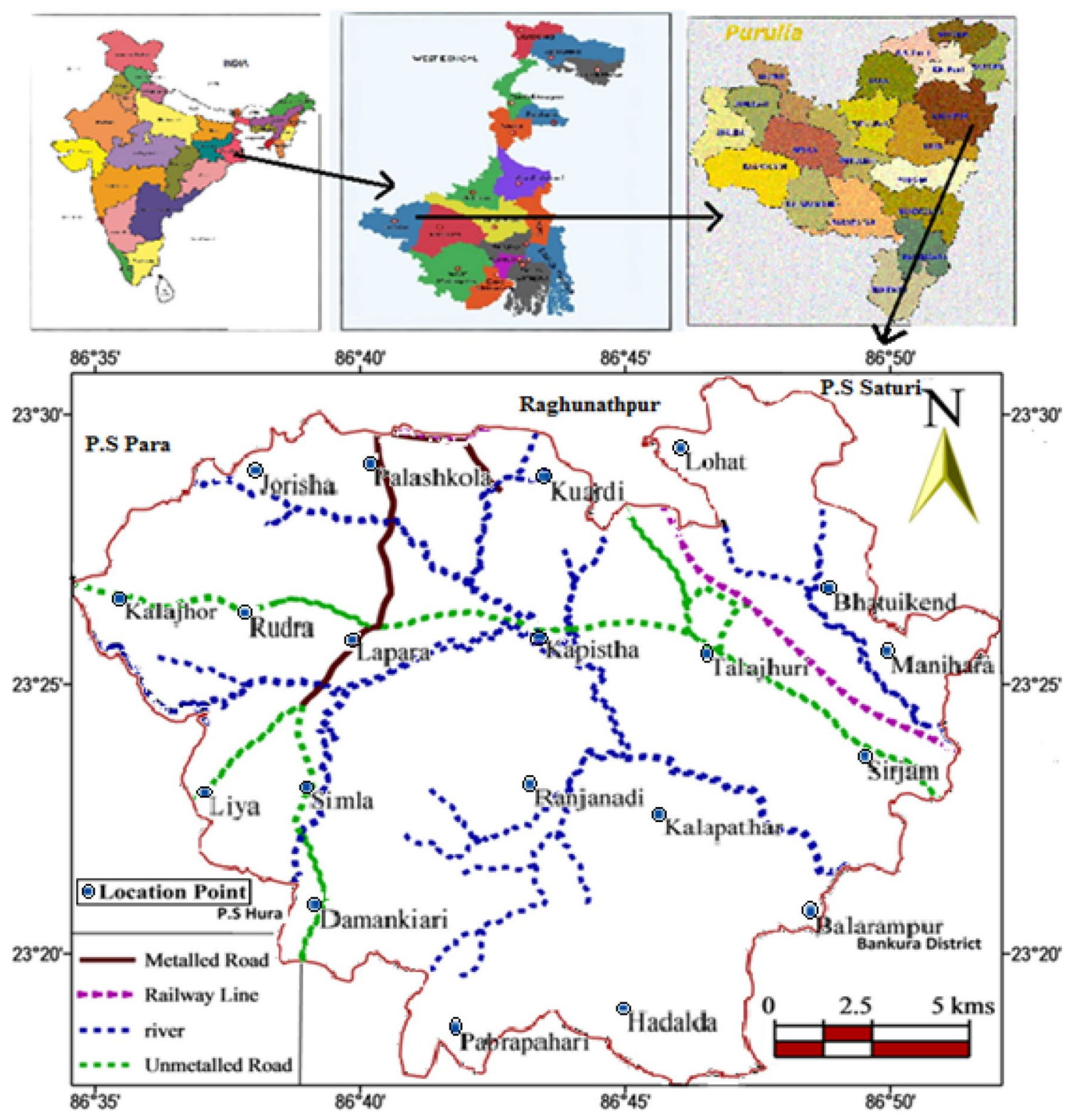

Fig. 1 Study area map

is sub- parallel and/or dendritic. The soil is of lateritic type with acidic in nature and low phosphorous content and it formed from the parent granitic rocks. The study area is characterized by gently to moderately rolling plain with lateritic uplands. Geologically, this soil is older but immature.

Granite gneiss belonging to the Chotanagpur Gneissic Complex constitutes the main rock types here. Mica schist is also present as band like formation and amphibolite is also found in this area in very small amount. Granite gneisses are hard, compact and foliated having fracture zones which act as conduit for surface water percolation. Mica schists are intensely foliated, fractured and is having good groundwater potentiality. Amphibolites are rather weathered, decomposed and can also transmit water.

\section{Materials and methods}

Twenty (20) groundwater samples each have been collected from bore wells for two different periods, post-monsoon in November 2014 and pre-monsoon in May 2015 (Fig. 1). Each sample was collected in acid-washed polyethylene $500 \mathrm{~mL}$ bottle. Before collection of water in a particular bottle, the bottle is rinsed thoroughly with the respective samples of the groundwater. Sample location is written on 
the bottle and suitable preservatives were added for storage till completion of quantitative chemical analysis. The bottle was filled to the brim with water taking care that no air bubble was trapped within the water sample. To prevent evaporation, the bottles were sealed with double plastic caps and precaution was also taken to avoid sample agitation during transfer to the laboratory. Immediately after collection, samples were transferred to the laboratory.

Electrical conductivity (EC) and $\mathrm{pH}$ were measured using Hanna portable $\mathrm{pH}-\mathrm{EC}-\mathrm{TDS}$ digital meters immediately after sampling. Water samples collected in the field were analyzed for chemical constituents, such as sodium, potassium, calcium, magnesium, chloride, bicarbonate, carbonate, sulphate, nitrate, fluoride, boron, silica and total dissolved solids (TDS), in the laboratory using the standard methods as suggested by the American Public Health Association (APHA 1995). $\mathrm{Ca}^{2+}, \mathrm{Mg}^{2+}, \mathrm{HCO}_{3}{ }^{-}, \mathrm{CO}_{3}{ }^{2-}, \mathrm{Cl}^{-}$were analysed by volume trictitrations.

Concentrations of $\mathrm{Ca}^{2+}$ and $\mathrm{Mg}^{2+}$ were estimated titrimetrically using $0.05 \mathrm{~N}$ EDTA and $0.01 \mathrm{~N}$. $\mathrm{H}_{2} \mathrm{SO}_{4}$ was used to determine the concentrations of $\mathrm{HCO}_{3}{ }^{-}$and $\mathrm{CO}_{3} . \mathrm{Cl}$ was estimated by Argentometric titration method using $\mathrm{AgNO}_{3}$. Flame photometer was used to measure $\mathrm{Na}^{+}$and $\mathrm{K}^{+}$ions. $\mathrm{SO}_{4}{ }^{2+}, \mathrm{NO}_{3}{ }^{-}, \mathrm{F}$ and $\mathrm{SiO}_{2}$ were determined by spectrophotometric techniques. The accuracy of the chemical analysis was verified by calculating ion balance errors where the errors were generally around $10 \%$.

The concentration of various ions as obtained from chemical analysis of ground water samples were converted to milliequivalent/litre (meq/L) and used to derive certain parameters. They are SAR, SSP, MAR, RSC, PI, KR and total hardness (TH). These parameters help to evaluate the irrigational suitability of ground water in the study area. Moreover, these values were plotted on graphical diagrams like U.S. Salinity, Wilcox, Doneen and Piper to determine the suitability of ground water for agricultural and drinking purposes.

Ionic balance of groundwater and fresh water determines the overall quality of water which is detected by the cationic and anionic concentrations (Huh et al. 1998). Ion balances have been calculated and examined for each ground-water sample as a quality-assurance check of the chemical analyses. The ion balance was calculated (in meq/L) as the total dissolved cationic concentration minus the total dissolved anion concentration divided by the total concentration of ions dissolved in solution. The total cations concentration was calculated as the sum of calcium, magnesium, sodium, and potassium; the total anions concentration was calculated as the sum of chloride, carbonate, bicarbonate and sulphate. The following equation is used:

Ion balance $=\left[100 *\left(\sum\right.\right.$ Cation $-\sum$ Anion $\left.)\right] /\left[\sum\right.$ Cation $+\sum$ Anion $]$ where, concentration of ions is expressed in meq/L.

\section{Results and discussion}

In the study area, the groundwater level ranges from 1.97 to $7.55 \mathrm{~m} \mathrm{bgl}$ in the post monsoon session, while in pre monsoon session it falls and ranges from 2.85 to $14.31 \mathrm{~m}$ bgl (Table 1). The groundwater level was minimum at Kapista village and maximum at Kalajhor village in both post monsoon and pre monsoon session. During postmonsoon and pre-monsoon time period water table of the block fluctuates vividly (Fig. 2), water table fluctuation is as high as $8.37 \mathrm{~m}$ at Damankiari village of the study area.

Identification of major geochemical reactions taking place in groundwater helps us to form an idea about the source and mechanisms playing significant roles in releasing the varied range of organic and inorganic components into water. Three parameters $\mathrm{pH}, \mathrm{EC}$ and TDS value ranges from 6.4 to $7.32,260$ to $2210 \mu \mathrm{S} / \mathrm{cm}$ and 130 to $1170 \mathrm{mg} / \mathrm{L}$ in post monsoon session, respectively, and $6.32-7.32,200-1820 \mu \mathrm{S} / \mathrm{cm}$ and $100-910 \mathrm{mg} / \mathrm{L}$ in pre monsoon session respectively (Table 2). In the study area, the variations of $\mathrm{pH}, \mathrm{EC}$ and TDS values have been shown in Figs. 3, 4 and 5, respectively. The results show that $\mathrm{pH}$ values are well within the permissible limit of WHO (2011). The range of EC values are higher than the permissible limit (> $300 \mathrm{mg} / \mathrm{L}$ ) (WHO 2011) in most of the cases. The level of TDS value is one of the deciding factors in the quality of drinking water. According to WHO (1984), the TDS values for drinking water should be less than $500 \mathrm{mg} / \mathrm{L}$ and according to ICMR (1975) maximum values will be $1500 \mathrm{mg} / \mathrm{L}$. Accordingly only 5 (25\%) samples of post-monsoon and 3 (15\%) samples of pre-monsoon are having values higher than $500 \mathrm{mg} / \mathrm{L}$. None of the samples are having values higher than $1500 \mathrm{mg} / \mathrm{L}$.

Weathering of primary minerals such as hornblende, mica, feldspar, calcite and dolomite are considered to be the sources of calcium and magnesium in groundwater (Nag and Suchetana 2016). Excess calcium and magnesium leads to hardness of water. Hard water leads to formation of scums and corrodes pipes. It interferes with the cleansing action of detergents. The concentration of calcium in the water samples collected vary from 11.76 to $288.96 \mathrm{mg} / \mathrm{L}$ with an average of $91.20 \mathrm{mg} / \mathrm{L}$ (postmonsoon) and $21.84-300.72 \mathrm{mg} / \mathrm{L}$ with an average of $79.5 \mathrm{mg} / \mathrm{L}$ (pre-monsoon). According to WHO (2011) and ICMR (1975) the limit of $\mathrm{Ca}$ content in drinking water is set as $75 \mathrm{mg} / \mathrm{L}$. In post-monsoon $12(60 \%)$ and

$$
\text { mand }
$$


Table 1 Water tables with regard to bore wells

\begin{tabular}{|c|c|c|c|c|}
\hline \multirow[t]{2}{*}{ Location name } & \multirow[t]{2}{*}{ Location } & \multicolumn{2}{|l|}{ Water tables (m) } & \multirow[t]{2}{*}{ Fluctuation (m) } \\
\hline & & $\begin{array}{l}\text { Post-monsoon (Novem- } \\
\text { ber 2014) (m) }\end{array}$ & $\begin{array}{l}\text { Pre-monsoon (April } \\
\text { 2015) (m) }\end{array}$ & \\
\hline Lapara & L1 & 181.48 & 178.88 & 2.60 \\
\hline Shimla & $\mathrm{L} 2$ & 180.01 & 175.65 & 4.36 \\
\hline Damankiari & L3 & 220.83 & 212.46 & 8.37 \\
\hline Pabra pahari & L4 & 221.43 & 216.15 & 5.28 \\
\hline Hadalda & L5 & 201.21 & 199.14 & 2.07 \\
\hline Balarampur & L6 & 156.89 & 150.47 & 6.42 \\
\hline Kalapathar & L7 & 156.38 & 155.64 & 0.74 \\
\hline Ranjanadi & L8 & 158.74 & 156.87 & 1.87 \\
\hline Liya & L9 & 185.12 & 181.52 & 3.60 \\
\hline Kalajhor & L10 & 226.62 & 222.00 & 4.62 \\
\hline Rudra & L11 & 228.27 & 207.00 & 1.18 \\
\hline Sirjam & L12 & 150.03 & 147.16 & 2.87 \\
\hline Manihara & L13 & 152.07 & 150.83 & 1.24 \\
\hline Bhatuikend & L14 & 158.13 & 153.58 & 4.55 \\
\hline Lohat & L15 & 170.01 & 167.02 & 2.99 \\
\hline Talajhuri & L16 & 164.73 & 162.49 & 2.24 \\
\hline Kapistha & L17 & 149.72 & 146.34 & 3.38 \\
\hline Kuardi & L18 & 183.95 & 182.18 & 1.77 \\
\hline Palashkola & L19 & 179.08 & 176.36 & 2.72 \\
\hline Jorisha & L20 & 205.17 & 202.17 & 3.00 \\
\hline
\end{tabular}

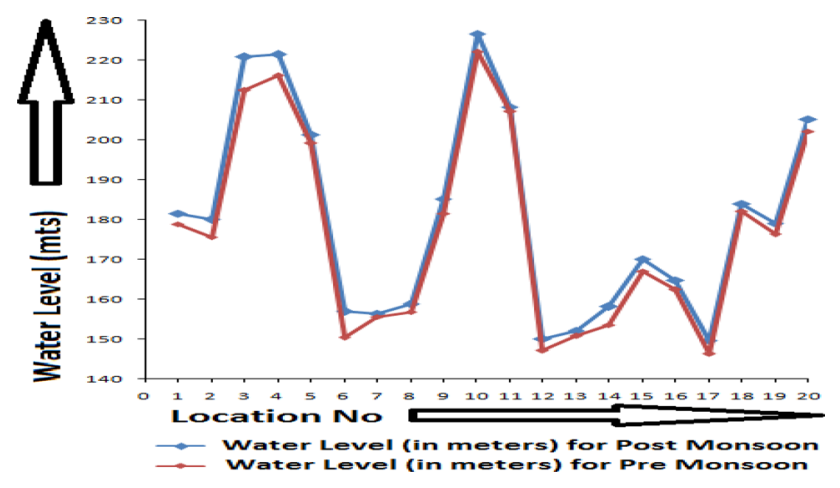

Fig. 2 Hydrograph representing variation in water tables (m) for both sampling sessions

in pre-monsoon $10(50 \%)$ samples are above the standard set by WHO and ICMR. The concentration of magnesium in the water samples collected vary from 16.61 to $159.63 \mathrm{mg} / \mathrm{L}$ with an average of $58.9 \mathrm{mg} / \mathrm{L}$ (post-monsoon) and 3.1-166.72 $\mathrm{mg} / \mathrm{L}$ with an average of $59.59 \mathrm{mg} / \mathrm{L}$ (pre-monsoon). The limit of $\mathrm{Mg}$ content in drinking water has been set as $50 \mathrm{mg} / \mathrm{L}$ by both WHO (2011) and ICMR (1975) and accordingly 7 (35\%) and 10 (50\%) samples are crossing the limit in post- and pre-monsoon respectively.

Sodium is a highly soluble chemical element which often occurs naturally in groundwater. Although it does not smell, it imparts awkward taste to the water at concentrations of
$200 \mathrm{mg} / \mathrm{L}$ or more. Common sodium bearing minerals are feldspars, sodalite and evaporites. Most compounds are highly water soluble. Increased intake of sodium in drinking water is detrimental to people suffering from hypertension, heart disease or kidney problems. The concentration of sodium in the water samples collected vary from 14 to $104 \mathrm{mg} / \mathrm{L}$ with an average of $65.15 \mathrm{mg} / \mathrm{L}$ (post-monsoon) and $9-56 \mathrm{mg} / \mathrm{L}$ with an average of $32.9 \mathrm{mg} / \mathrm{L}$ (pre-monsoon). Hence all samples are within permissible limit, i.e., less than $200 \mathrm{mg} / \mathrm{L}$.

Potassium controls body balance and maintains normal growth of the human body. Deficiency of potassium might lead to weakness of muscles and rise in blood pressure. The concentration of potassium in the water samples collected vary from 0.5 to $7.4 \mathrm{mg} / \mathrm{L}$ with an average of $2.46 \mathrm{mg} / \mathrm{L}$ (post-monsoon) and $9-63 \mathrm{mg} / \mathrm{L}$ with an average of $28.5 \mathrm{mg} / \mathrm{L}$ (pre-monsoon).

Chloride is found naturally in groundwater through the weathering and leaching of sedimentary rocks and soils and the dissolution of salt deposits. Chloride is often attached to sodium, in the form of sodium chloride $(\mathrm{NaCl})$. Sodium chloride imparts saline taste to water. The concentration of chloride in the water samples collected vary from 10.00 to $374.88 \mathrm{mg} / \mathrm{L}$ with an average of $130.71 \mathrm{mg} / \mathrm{L}$ (post-monsoon) and $59.98-414.87 \mathrm{mg} / \mathrm{L}$ with an average of $151.21 \mathrm{mg} / \mathrm{L}$ (pre-monsoon). The limit of chloride in drinking water has been set as $<200 \mathrm{mg} / \mathrm{L}$ (WHO 2011) 


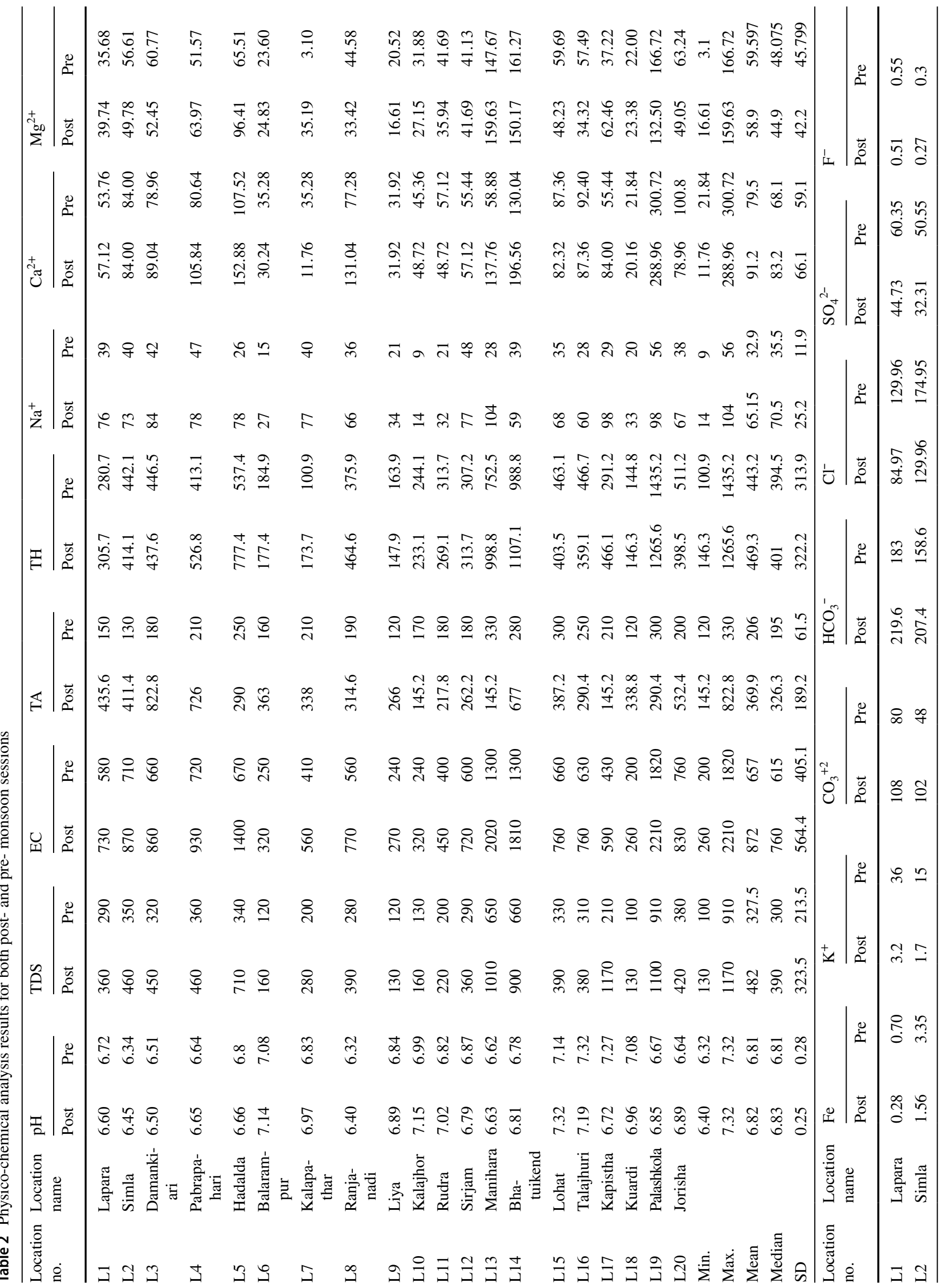




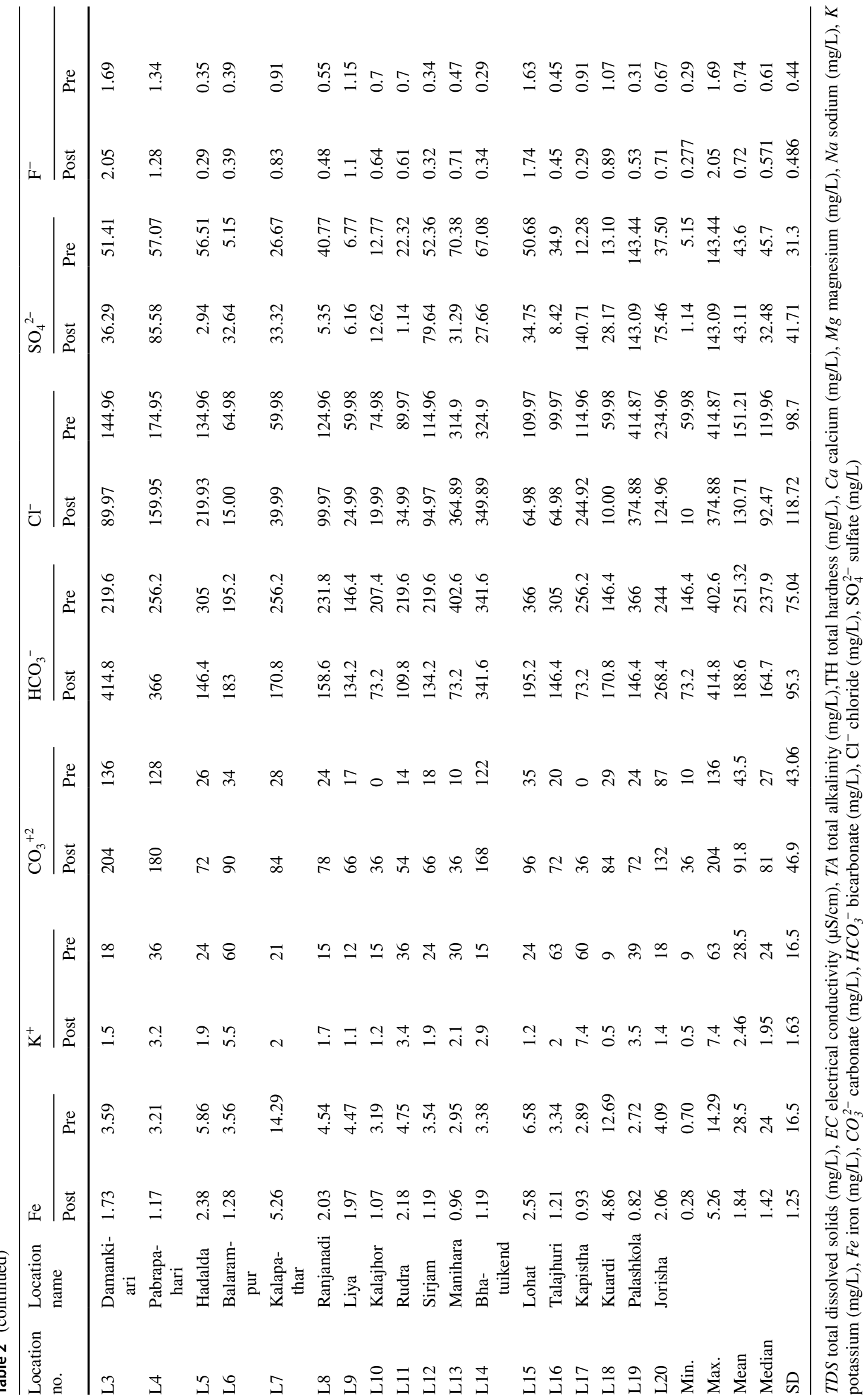




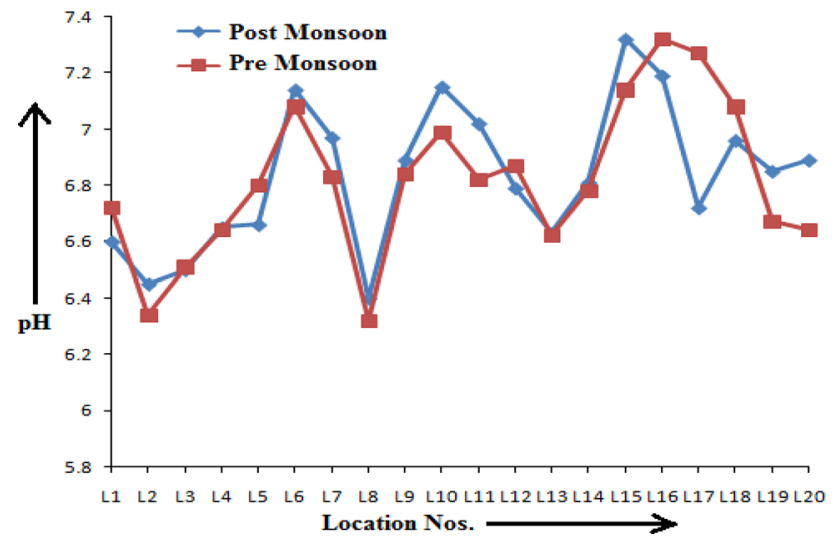

Fig. 3 Spatio-temporal variation in $\mathrm{pH}$ value in the study area

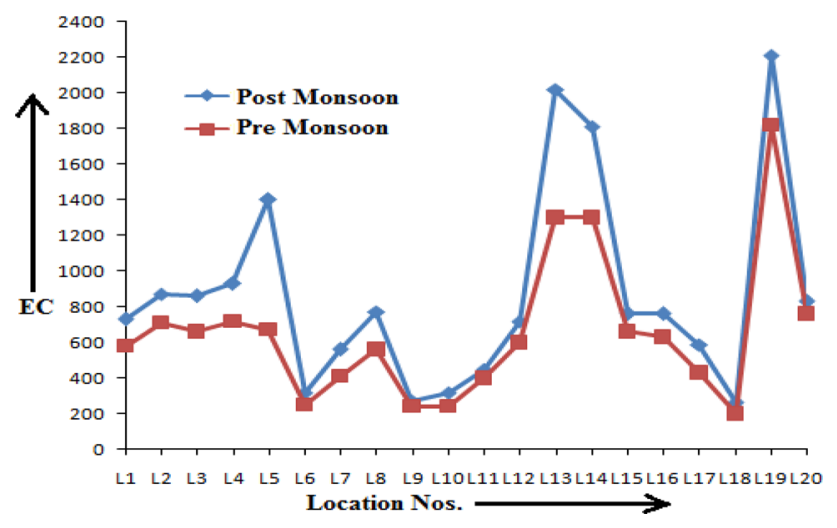

Fig. 4 Spatio-temporal variation in EC value in the study area

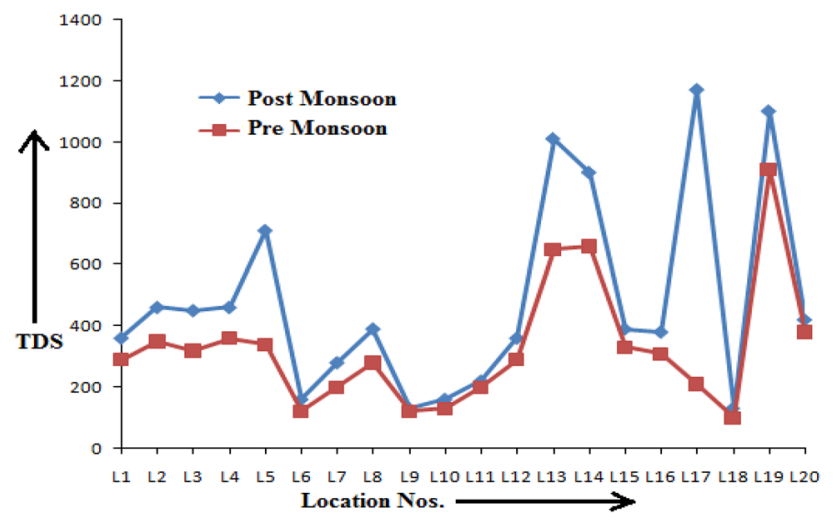

Fig. 5 Spatio-temporal variation in TDS value in the study area

and $<250 \mathrm{mg} / \mathrm{L}$ (ICMR 1975) and accordingly 5 (25\%) and $4(20 \%)$ samples are having values crossing the limit of WHO (2011) in post- and pre-monsoon respectively. Following ICMR standard, only $15 \%$ samples both in postand pre-monsoon period are crossing the limit.
The concentration of bicarbonate in the water samples collected vary from 73.2 to $414.8 \mathrm{mg} / \mathrm{L}$ with an average of $188.6 \mathrm{mg} / \mathrm{L}$ (post-monsoon) and $146.4-402.6 \mathrm{mg} / \mathrm{L}$ with an average of $251.32 \mathrm{mg} / \mathrm{L}$ (pre-monsoon).

Sulphate ions do not have any significant detrimental effect on plants and animals. It is essential nutrient for plants. At levels above $1000 \mathrm{mg} / \mathrm{L}$, sulphate in drinking water can have a laxative effect. Sulphur bacteria may produce a dark slime or deposits of metal oxides that develop as a result of the corrosion of metal pipes. Sulfate ion varied from 1.14 to $143.09 \mathrm{mg} / \mathrm{L}$ during the post-monsoon with an average of $43.11 \mathrm{mg} / \mathrm{L}$ and from 5.15 to $143.44 \mathrm{mg} / \mathrm{L}$ in pre-monsoon seasons with an average of $43.6 \mathrm{mg} / \mathrm{L}$. The standard limit of sulfate in drinking water has been set as $200 \mathrm{mg} / \mathrm{L}$ and all the studied samples are having values $<200 \mathrm{mg} / \mathrm{L}$.

Total alkalinity value of water gives us an idea of natural salts present in water. Alkalinity of water is its capacity to neutralize a strong acid and it is normally due to the presence of bicarbonates, carbonates and hydroxide compounds of calcium, sodium and potassium. According to BIS (2012) the permissible range of TA in groundwater is $200-600 \mathrm{mg} / \mathrm{L}$. The total alkalinity values for all the investigated samples were found to be greater in post-monsoon samples L3, L4 and L13 (total three) exceeds the range whereas all samples in pre-monsoon fall within the prescribed range.

The trend amongst average ionic concentrations of cations and anions is $\mathrm{Mg}^{2+}>\mathrm{Ca}^{2+}>\mathrm{Na}^{+}>\mathrm{Fe}>\mathrm{K}^{+}$ and $\mathrm{Cl}^{-}>\mathrm{HCO}_{3}{ }^{-}>\mathrm{CO}_{3}{ }^{2-}>\mathrm{SO}_{4}{ }^{2-}>\mathrm{F}^{-}$, respectively during the post monsoon whereas the trend for cations and anions are $\mathrm{Mg}^{2+}>\mathrm{Ca}^{2+}>\mathrm{Na}^{+}>\mathrm{K}^{+}>\mathrm{Fe}$ and $\mathrm{Cl}^{-}>\mathrm{HCO}_{3}{ }^{-}>\mathrm{SO}_{4}{ }^{2-}>\mathrm{F}^{-}>\mathrm{CO}_{3}{ }^{-}$in pre monsoon session respectively. Graphical presentations of all cations and anions values with the sample locations of both sessions have been shown in Figs. 6 and 7, respectively.

Ionic balance of groundwater has also been done for a quality-assurance check of the chemical analyses. According to standard rules, the ion balance of a fresh water sample with low TDS is considered to be good if the value is between $-10 \%$ and $+10 \%$. Table 3 represents the ion balance of samples collected during post monsoon and pre monsoon period and Fig. 8 represents the ion balance histogram of the study area.

\section{Irrigation water quality}

The overall irrigational water quality of the samples collected, certain parameters have been derived. These include: (1) SAR, (2) SSP, (3) PI, (4) RSC, (5) MAR and (6) KR (Ishaku 2011; Obiefuna and Sheriff 2011). The derived parameters are shown in Table 4. Table 5 represents classification of samples according to standards specified for different water quality parameters. 

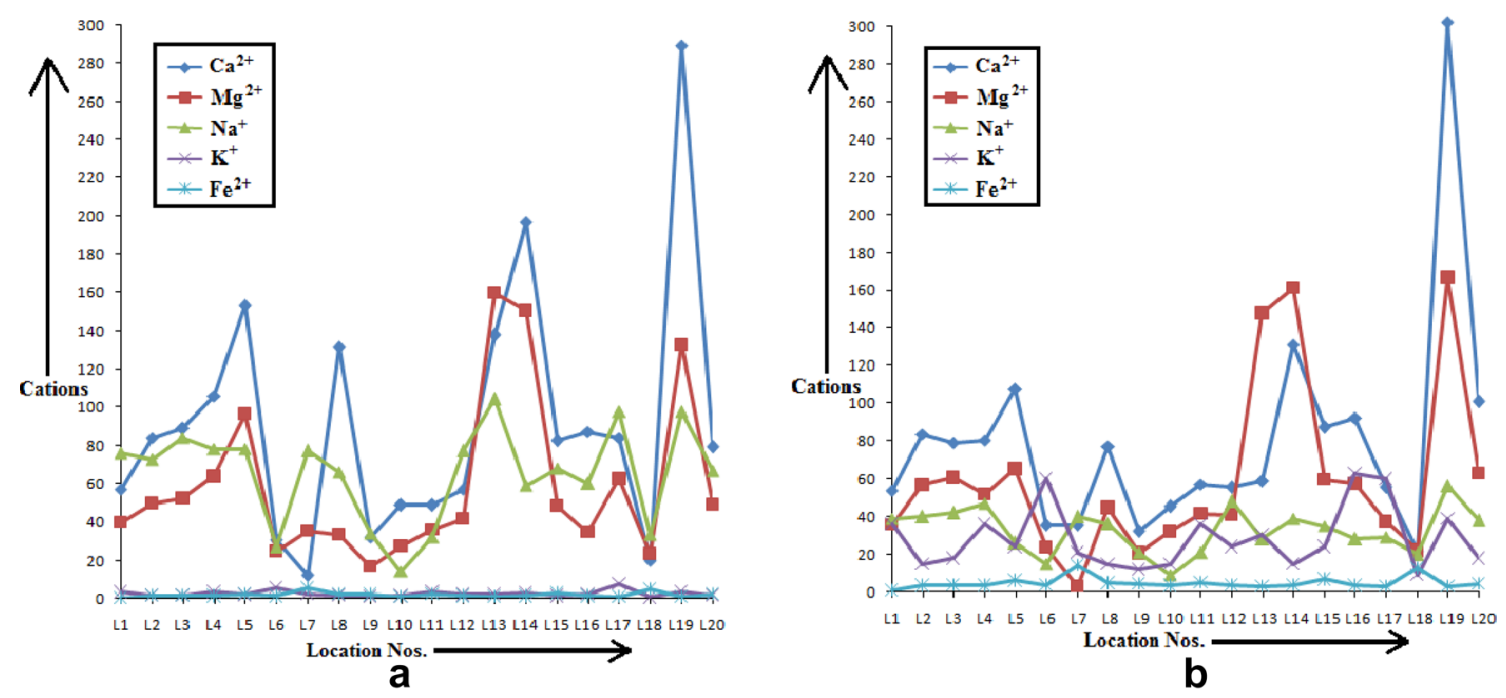

Fig. 6 Spatio-temporal variation of cations in the study area (a post monsoon, b pre monsoon)
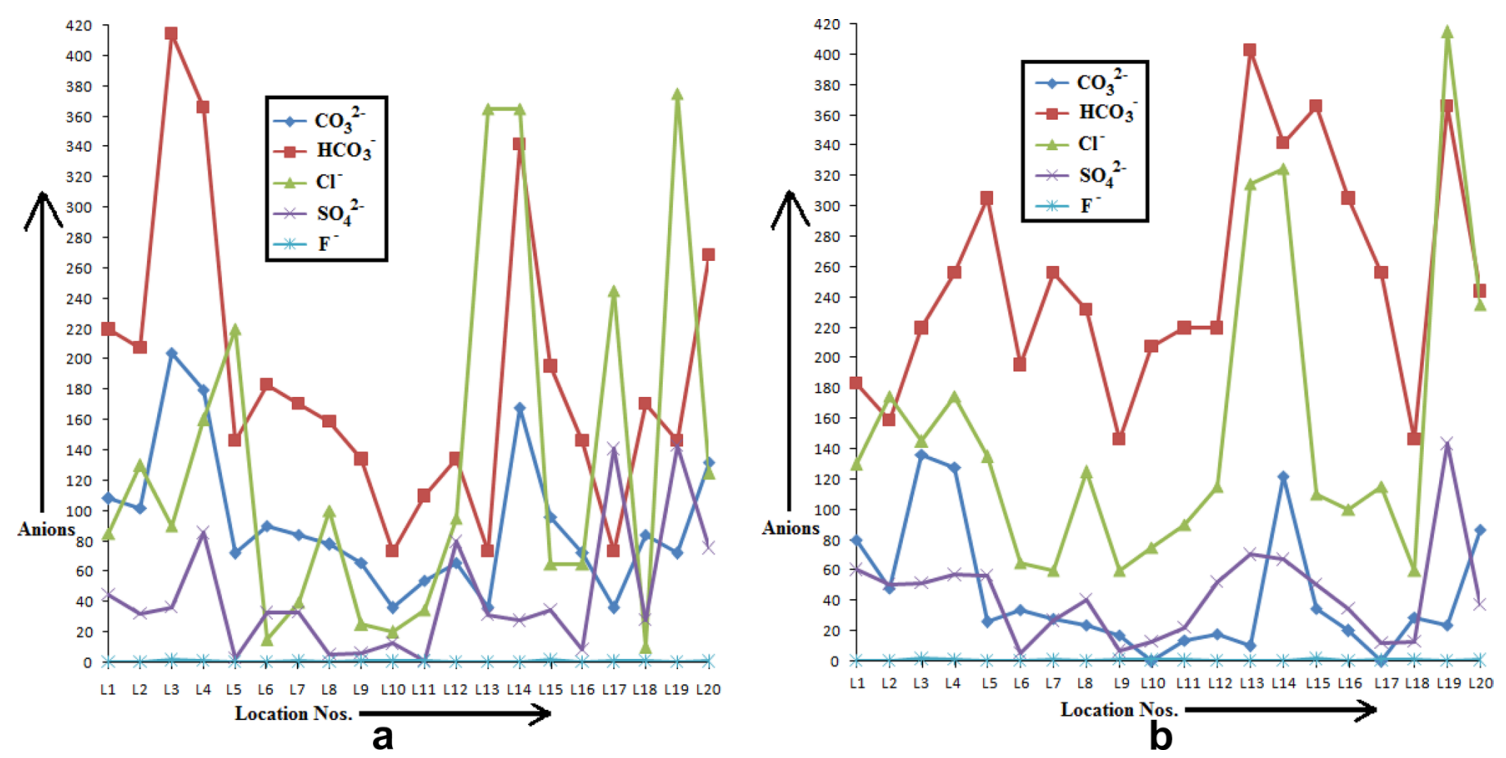

Fig. 7 Spatio-temporal variation of anions in the study area (a post monsoon, b pre monsoon)

\section{Sodium adsorption ratio (SAR)}

The SAR was calculated using the following equation (Richards 1954):

$\mathrm{SAR}=\left(\mathrm{Na}^{+}\right) /\left\{\left[\left(\mathrm{Ca}^{2+}\right)+\left(\mathrm{Mg}^{2+}\right)\right] / 2\right\}^{1 / 2}$

Concentrations of all ions have been expressed in meq/L.

High sodium concentration leads to development of alkaline soil. Alkaline soils are difficult to take into agricultural production. Due to the low infiltration capacity, rain water stagnates on the soil easily and, in dry periods, cultivation is hardly possible without copious irrigated water and good drainage. SAR values are plotted against EC values along $y$-axis and $x$-axis, respectively, in U.S. Salinity diagram to classify water samples. In the present study, the SAR values range from 0.39 to 2.52 in post-monsoon with an average value of 1.39 and $0.25-1.73$ during pre-monsoon with an average value of 0.75 (Table 4). Based on the SAR values all samples have low sodium hazard and on plotting over the U.S. Salinity diagram (1954) (Fig. 9), the water samples fall in the $\mathrm{C} 2-\mathrm{S} 1$ and $\mathrm{C} 3-\mathrm{S} 1$ classes (post-monsoon) and $\mathrm{C} 1-\mathrm{S} 1$, $\mathrm{C} 2-\mathrm{S} 1$ and $\mathrm{C} 3-\mathrm{S} 1$ classes (pre monsoon), so it can be stated that in both sessions the waters of the area fall under 'Good' category for irrigation purposes. 
Table 3 Ion balance values of groundwater samples of the study area

\begin{tabular}{llrr}
\hline Location no. & Location name & Ion balance & \\
\cline { 3 - 4 } & & Post monsoon & Pre monsoon \\
\hline L1 & Lapara & -2.71 & 6.15 \\
L2 & Simla & 3.37 & 15.54 \\
L3 & Damankiari & -14.09 & 15.25 \\
L4 & Pabrapahari & -10.67 & 7.12 \\
L5 & Hadalda & 26.78 & 14.42 \\
L6 & Balarampur & -16.16 & 7.37 \\
L7 & Kalapathar & -1.41 & -18.23 \\
L8 & Ranjanadi & 20.41 & 10.14 \\
L9 & Liya & -7.61 & 3.49 \\
L10 & Kalajhor & 26.09 & 0.16 \\
L11 & Rudra & 19.76 & 12.08 \\
L12 & Sirjam & 10.23 & 9.19 \\
L13 & Manihara & 31.01 & 2.99 \\
L14 & Bhatuikend & 6.84 & 17.59 \\
L15 & Lohat & 12.31 & 8.34 \\
L16 & Talajhuri & 18.92 & 19.74 \\
L17 & Kapistha & 12.48 & 6.48 \\
L18 & Kuardi & -17.11 & -3.09 \\
L19 & Palashkola & 27.74 & 25.53 \\
L20 & Jorisha & -8.95 & 5.88 \\
\hline
\end{tabular}

\section{Soluble sodium percentage (SSP)}

It is calculated by the following equation (Todd 1980):

$$
\mathrm{SSP}=\left[\left(\mathrm{Na}^{+}+\mathrm{K}^{+}\right) * 100\right] /\left[\mathrm{Ca}^{2+}+\mathrm{Mg}^{2+}+\mathrm{Na}^{+}+\mathrm{K}^{+}\right]
$$

All concentrations are in meq/L.

When concentration of sodium ion is high in irrigated water, it tends to be absorbed by clay particles, dispersing magnesium and calcium ions. This exchange process of sodium in water for $\mathrm{Ca}^{2+}$ and $\mathrm{Mg}^{2+}$ in soil reduces the permeability and eventually results in soil with poor internal draining. The SSP values range from 10.56 to 49.12 in post monsoon with an average value of 26.31 and $9.42-52.95$ during pre-monsoon with an average value of 23.24 (Table 4). Wilcox (1948) diagram (Fig. 10) is used for classification of irrigation waters. $x$-axis represented by EC and $y$-axis represented by SSP. In post-monsoon period seventeen of the samples are in "excellent to good" while three are in "good to permissible" category. In pre-monsoon samples most are in "excellent to good category", two are in "good to permissible" category.

\section{Permeability index (PI)}

The permeability of soil is affected by sodium, calcium, magnesium and bicarbonate contents of irrigation water. Doneen (1964) calculated the permeability index based on the formula

$\left.\mathrm{PI}=\left\{\left[\mathrm{Na}+\left(\mathrm{HCO}_{3}\right)^{1 / 2}\right)\right] * 100\right\} /(\mathrm{Ca}+\mathrm{Mg}+\mathrm{Na})$

All concentrations are in meq/L.

PI varies from 19.53 to 73.11 with an average value of 43.93 in post-monsoon period and from 15.57 to 100.72 in pre-monsoon period with an average value of 41.46 (Table 4). Doneen's chart for pre- and post-monsoon sessions are presented in Fig. 11, respectively. During postmonsoon, 17 (seventeen) samples are in Class I category (> 75\% permeability), 3 (three) samples are in Class II category $(25-75 \%)$ permeability. During pre-monsoon, 17 (seventeen) samples are in Class I category ( $>75 \%$ permeability) and 2 (two) samples are in Class II category (25-75\% permeability) and 1 (one) sample is in Class III category $(<25 \%)$ permeability.

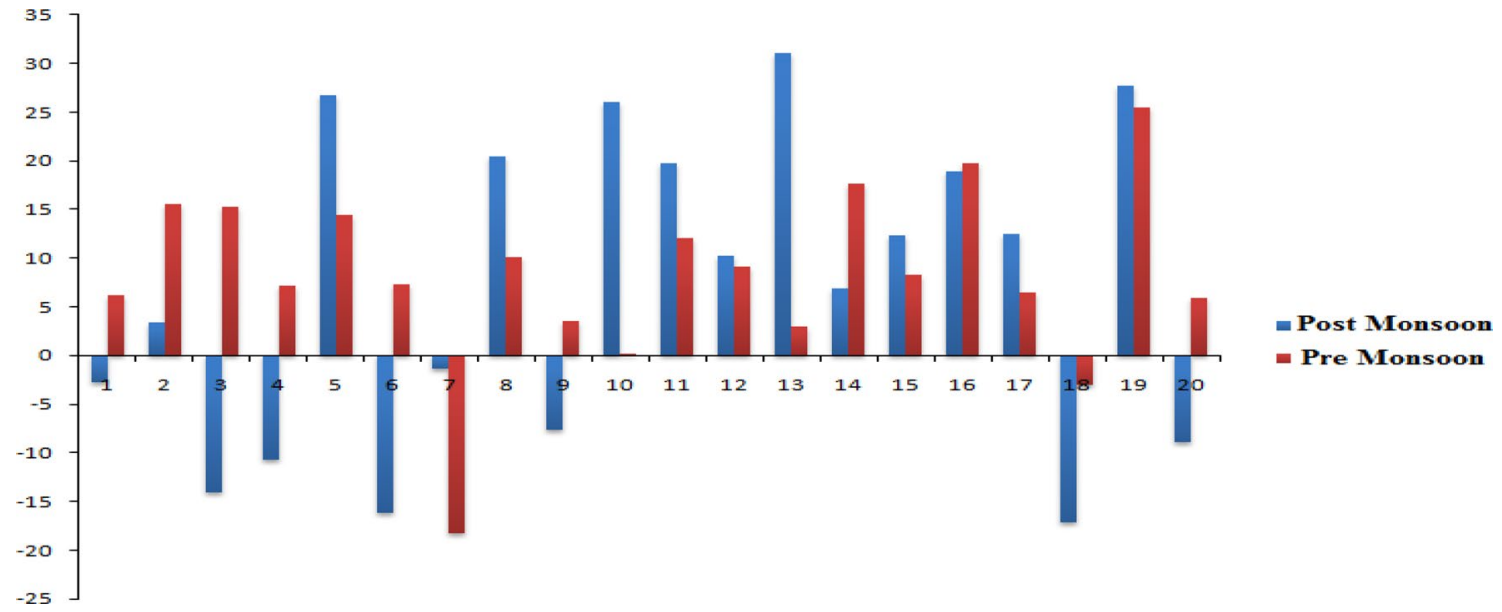

Fig. 8 Ion balance histogram 
Table 4 Values of water quality indices

\begin{tabular}{|c|c|c|c|c|c|c|c|c|c|c|c|c|c|c|c|}
\hline \multirow[t]{2}{*}{ Location no. } & \multirow[t]{2}{*}{ Location name } & \multicolumn{2}{|l|}{ SAR } & \multicolumn{2}{|l|}{ SSP } & \multicolumn{2}{|l|}{ PI } & \multicolumn{2}{|l|}{ RSC } & \multicolumn{2}{|l|}{ MAR } & \multicolumn{2}{|l|}{ KR } & \multicolumn{2}{|l|}{$\mathrm{TH}$} \\
\hline & & Post & Pre & Post & Pre & Post & Pre & Post & Pre & Post & Pre & Post & Pre & Post & Pre \\
\hline L1 & Lapara & 1.88 & 1.01 & 35.44 & 31.61 & 54.92 & 46.59 & 1.03 & 0.05 & 53.69 & 52.52 & 0.54 & 0.29 & 305.73 & 280.69 \\
\hline L2 & Simla & 1.55 & 0.82 & 27.82 & 19.23 & 43.55 & 31.45 & -1.55 & -4.65 & 49.69 & 52.90 & 0.38 & 0.19 & 414.10 & 442.10 \\
\hline L3 & Damankiari & 1.74 & 0.86 & 29.49 & 20.24 & 50.18 & 34.35 & 4.78 & -0.81 & 49.54 & 56.19 & 0.41 & 0.20 & 437.65 & 446.56 \\
\hline L4 & Pabra & 1.47 & 1.00 & 24.64 & 26.24 & 41.68 & 39.46 & 1.38 & 0.20 & 50.18 & 51.59 & 0.32 & 0.25 & 526.88 & 413.04 \\
\hline L5 & Hadalda & 1.21 & 0.49 & 17.99 & 13.87 & 25.91 & 28.13 & -10.88 & -4.89 & 51.24 & 50.38 & 0.22 & 0.10 & 777.48 & 537.39 \\
\hline L6 & Balarampur & 0.88 & 0.48 & 26.85 & 36.95 & 61.11 & 55.69 & 2.42 & 0.63 & 57.78 & 52.72 & 0.33 & 0.17 & 177.40 & 184.96 \\
\hline L7 & Kalapathar & 2.52 & 1.73 & 49.12 & 52.95 & 73.11 & 100.72 & 2.08 & 3.12 & 83.29 & 12.77 & 0.95 & 0.86 & 173.68 & 100.91 \\
\hline L8 & Ranjanadi & 1.33 & 0.81 & 23.78 & 20.45 & 36.72 & 38.43 & -4.14 & -2.93 & 29.83 & 49.02 & 0.31 & 0.21 & 464.62 & 375.98 \\
\hline L9 & Liya & 1.21 & 0.71 & 33.58 & 26.95 & 66.42 & 58.36 & 1.42 & -0.32 & 46.45 & 51.72 & 0.49 & 0.28 & 147.90 & 163.93 \\
\hline L10 & Kaljhor & 0.39 & 0.25 & 11.98 & 13.59 & 32.11 & 42.05 & -2.29 & -1.49 & 48.15 & 53.95 & 0.13 & 0.08 & 233.12 & 244.11 \\
\hline 11 & Rudra & 0.84 & 0.51 & 21.39 & 22.46 & 40.05 & 38.80 & -1.83 & -2.22 & 55.15 & 54.88 & 0.26 & 0.14 & 269.15 & 313.73 \\
\hline L12 & Sirjam & 1.88 & 1.18 & 34.92 & 30.34 & 49.92 & 48.08 & -1.93 & -1.95 & 54.88 & 55.29 & 0.53 & 0.34 & 313.73 & 307.23 \\
\hline L13 & Manihara & 1.42 & 0.44 & 18.48 & 11.52 & 22.73 & 22.99 & -17.79 & -8.16 & 65.89 & 80.72 & 0.22 & 0.08 & 998.88 & 752.65 \\
\hline L14 & Bhatuikend & 0.77 & 0.54 & 10.56 & 9.42 & 19.79 & 18.73 & -11.14 & -10.10 & 56.01 & 67.23 & 0.11 & 0.09 & 1107.10 & 986.31 \\
\hline L15 & Lohat & 1.47 & 0.70 & 26.86 & 18.61 & 42.78 & 36.55 & -1.73 & -2.18 & 49.41 & 53.24 & 0.36 & 0.16 & 403.54 & 463.13 \\
\hline L16 & Talajhuri & 1.37 & 0.56 & 26.90 & 23.11 & 42.27 & 32.49 & -2.43 & -3.74 & 39.57 & 50.91 & 0.36 & 0.13 & 359.11 & 466.71 \\
\hline L17 & Kapistha & 1.97 & 0.74 & 32.12 & 32.25 & 39.19 & 46.39 & -7.01 & -1.67 & 55.34 & 52.81 & 0.45 & 0.22 & 466.09 & 291.20 \\
\hline L18 & Kuardi & 1.18 & 0.72 & 32.87 & 27.32 & 70.78 & 63.74 & 2.64 & 0.47 & 65.90 & 62.67 & 0.49 & 0.29 & 146.26 & 144.8 \\
\hline L19 & Palashkola & 1.19 & 0.64 & 14.58 & 10.61 & 19.53 & 15.57 & -20.69 & -22.12 & 43.32 & 48.02 & 0.17 & 0.08 & 1265.65 & 1435.35 \\
\hline L20 & Jorisha & 1.45 & 0.73 & 26.85 & 17.01 & 45.77 & 30.53 & 0.76 & -3.34 & 50.87 & 51.12 & 0.36 & 0.16 & 398.51 & 511.28 \\
\hline Min. & & 0.39 & 0.25 & 10.56 & 9.42 & 19.53 & 15.57 & -20.69 & -22.12 & 29.83 & 12.77 & 0.11 & 0.08 & 146.268 & 100.91 \\
\hline Max. & & 2.52 & 1.73 & 49.12 & 52.95 & 73.11 & 100.72 & 4.78 & 3.12 & 83.30 & 80.72 & 0.95 & 0.86 & 1265.65 & 1435.35 \\
\hline Mean & & 1.39 & 0.75 & 26.31 & 23.24 & 43.93 & 41.46 & -3.35 & -3.31 & 52.81 & 53.03 & 0.37 & 0.22 & 469.33 & 443.10 \\
\hline Median & & 1.39 & 0.72 & 26.86 & 21.46 & 42.53 & 38.62 & -1.78 & -2.06 & 51.06 & 52.76 & 0.36 & 0.19 & 401.02 & 394.51 \\
\hline SD & & 0.48 & 0.32 & 9.11 & 10.45 & 15.83 & 18.77 & 6.88 & 5.37 & 10.82 & 12.06 & 0.19 & 0.17 & 322.19 & 313.74 \\
\hline
\end{tabular}

\section{Residual sodium carbonate (RSC)}

The RSC is calculated according to (Raghunath 1987):

$\mathrm{RSC}=\left(\mathrm{CO}_{3}+\mathrm{HCO}_{3}\right)-(\mathrm{Ca}+\mathrm{Mg})$

All concentrations are in meq/L.

When the sum of carbonates and bicarbonates is in excess of calcium and magnesium, there may be a possibility of complete precipitation of calcium carbonate and magnesium carbonate. The concentration of $\mathrm{Ca}$ and $\mathrm{Mg}$ decreases relative to sodium and the SAR index will be bigger. This will cause an alkalizing effect and increase the $\mathrm{pH}$.

RSC values less than 1.25 are considered safe for irrigation. During post-monsoon period, only $70 \%$ samples are safe for irrigation with RSC values less than $1.25 ; 20 \%$ samples are marginally suitable with RSC values between 1.25 and 2.5 and remaining $10 \%$ samples have RSC values greater than 2.5, hence unsuitable for irrigation. During premonsoon period $95 \%$ samples have RSC values less than 1.25 and are considered to be safe. Rest 5\% samples are marginally suitable with RSC values between 1.25 and 2.5 (Table 5).

\section{Magnesium adsorption ratio (MAR)}

Magnesium is essential for plant growth, but excess magnesium can have severe toxicity effect on plants. Excess magnesium in soil reduces the availability of potassium. Leaves develop coppery color along the marginal veins in the initial stage. Extensive coppery color develops all over the leaf surface and defoliation of leaf occurs during the final stage of toxicity. MAR is calculated by the equation (Raghunath 1987) as:

$\mathrm{MAR}=(\mathrm{Mg} * 100) /(\mathrm{Ca}+\mathrm{Mg})$

All concentrations are in meq/L.

MAR is broadly classified into two groups. Less than 50 values of groundwater are considered to be suitable for irrigation whereas greater than 50 values are unsuitable. During post-monsoon period, the minimum and maximum values are 29.83 and 83.30, respectively, with an average value of 52.81 (Table 4). During post-monsoon period, only $40 \%$ samples are suitable for irrigation and $60 \%$ samples have MAR values greater than 50. During pre-monsoon period, the minimum and maximum values are 12.77 and 80.72 , 
Table 5 Classification according to calculated parameters standards

\begin{tabular}{|c|c|c|c|c|c|c|}
\hline \multirow[t]{2}{*}{ Parameters } & \multirow[t]{2}{*}{ Range } & \multirow[t]{2}{*}{ Class } & \multicolumn{2}{|l|}{ No. of samples } & \multicolumn{2}{|c|}{ Percentage of samples } \\
\hline & & & Post-monsoon & Pre-monsoon & Post-monsoon & Pre-monsoon \\
\hline \multirow[t]{4}{*}{ EC } & $<250$ & Excellent & 0 & 3 & 0 & 15 \\
\hline & $250-750$ & Good & 9 & 13 & 45 & 65 \\
\hline & $750-2250$ & Permissible & 11 & 4 & 55 & 20 \\
\hline & $>2250$ & Unsuitable & 0 & 0 & 0 & 0 \\
\hline \multirow[t]{4}{*}{ SAR } & $0-10$ & Excellent & 20 & 20 & 100 & 100 \\
\hline & $10-18$ & Good & 0 & 0 & 0 & 0 \\
\hline & $18-26$ & Permissible & 0 & 0 & 0 & 0 \\
\hline & $>26$ & Doubtful & 0 & 0 & 0 & 0 \\
\hline \multirow[t]{5}{*}{ SSP } & $<20$ & Excellent & 5 & 8 & 45 & 40 \\
\hline & $20-40$ & Good & 14 & 11 & 70 & 55 \\
\hline & $40-60$ & Permissible & 1 & 1 & 5 & 5 \\
\hline & $60-80$ & Doubtful & 0 & 0 & 0 & 0 \\
\hline & $>80$ & Unsuitable & 0 & 0 & 0 & 0 \\
\hline \multirow[t]{2}{*}{ MAR } & $\leq 50$ & Suitable & 8 & 3 & 40 & 15 \\
\hline & $>50$ & Unsuitable & 12 & 17 & 60 & 85 \\
\hline \multirow[t]{3}{*}{ RSC } & $<1.25$ & Low & 14 & 19 & 70 & 95 \\
\hline & $1.25-2.50$ & Medium & 4 & 1 & 20 & 5 \\
\hline & $>2.50$ & High & 2 & 0 & 10 & 0 \\
\hline \multirow[t]{3}{*}{ PI } & $<80$ & Good & 20 & 19 & 100 & 95 \\
\hline & 80-100 & Moderate & 0 & 0 & 0 & 0 \\
\hline & $100-120$ & Poor & 0 & 1 & 0 & 5 \\
\hline \multirow[t]{2}{*}{ KR } & $\leq 1$ & Suitable & 20 & 20 & 100 & 100 \\
\hline & $>1$ & Unsuitable & 0 & 0 & 0 & 0 \\
\hline \multirow[t]{5}{*}{ WQI } & $<50$ & Excellent & 0 & 0 & 0 & 0 \\
\hline & $50-100$ & Good & 9 & 9 & 45 & 45 \\
\hline & $100-200$ & Poor & 10 & 9 & 50 & 45 \\
\hline & $200-300$ & Very poor & 1 & 2 & 5 & 10 \\
\hline & $>300$ & Unfit for drinking & 0 & 1 & 0 & 5 \\
\hline
\end{tabular}

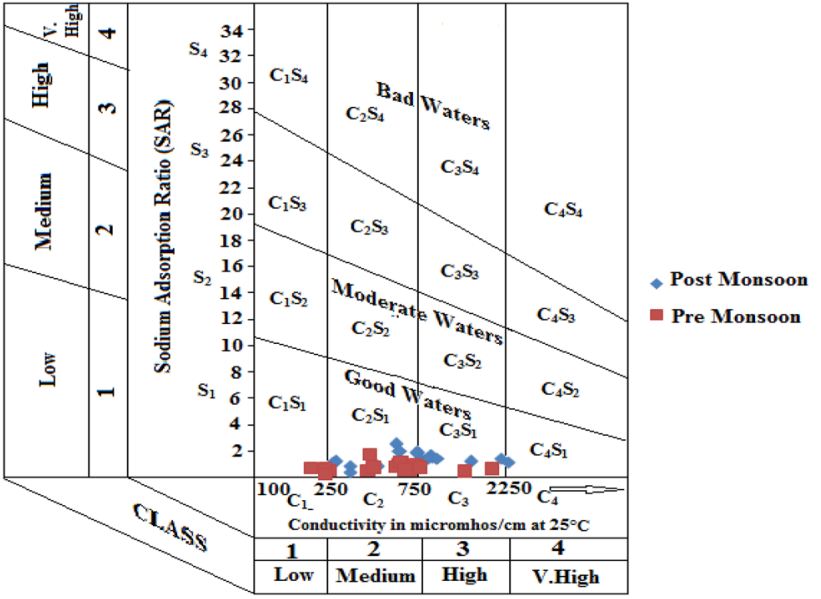

Fig. 9 U.S. salinity diagram

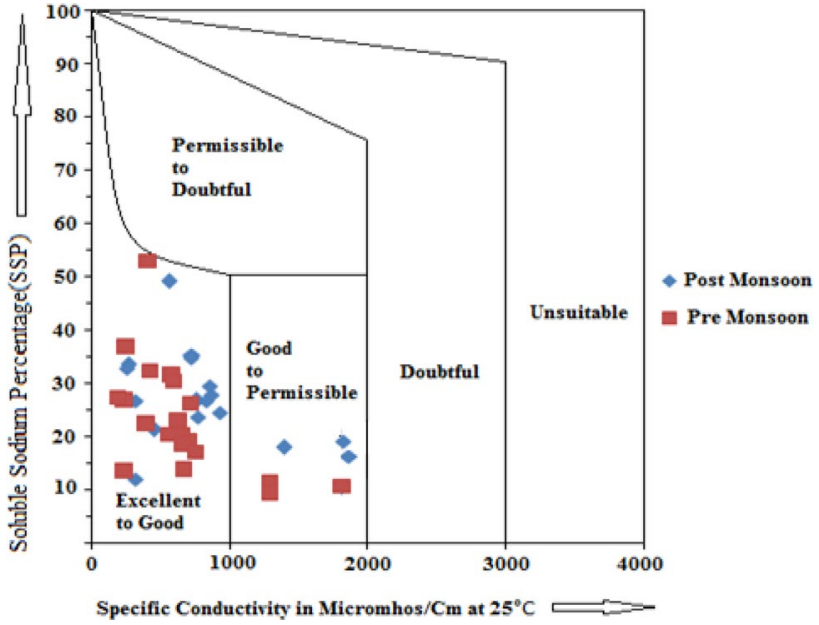

Fig. 10 Wilcox diagram 


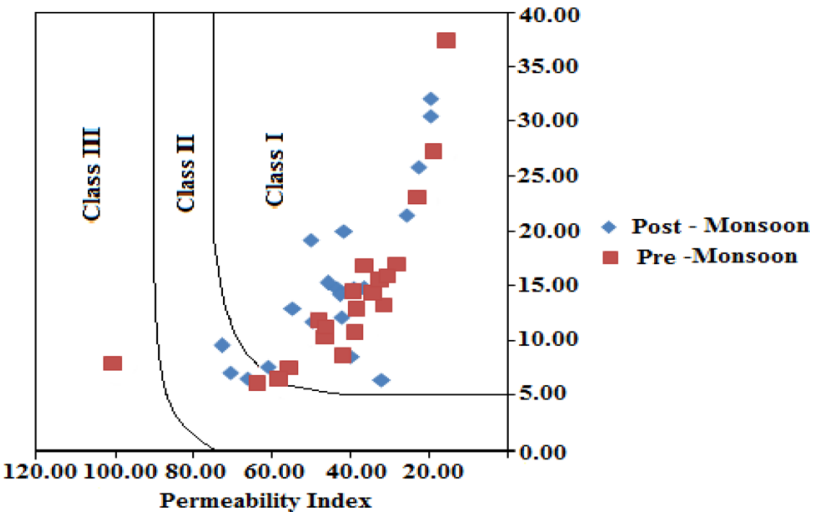

Fig. 11 Doneen's chart

respectively. During pre-monsoon period, only $15 \%$ samples are suitable for irrigation and $85 \%$ samples have MAR values greater than 50 (Table 5). Overall the MAR values are quite high for both seasons.

Kelly's ratio (KR) Kelly (1976) devised an equation for the sodium problem in water.

$\mathrm{KR}=\mathrm{Na} /(\mathrm{Ca}+\mathrm{Mg})$

Water having KR value less than 1 is considered suitable for irrigation. All the 20 post-monsoon as well as pre-monsoon samples have $\mathrm{KR}$ values less than 1 ; hence the water is fit for irrigation (Table 5).

\section{Drinking water suitability}

In many parts of our country, the groundwater, be it from dug wells or bore wells, form the major source of drinking water. In our present study, we determined standards of

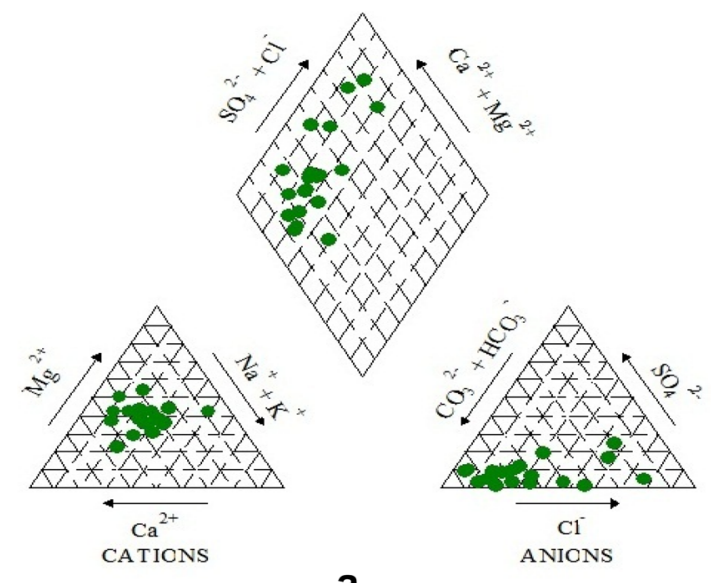

a

Fig. 12 Piper diagram. a Post monsoon, b pre monsoon groundwater from TH, plotting in the Piper's diagram and also from water quality index (WQI).

\section{Total hardness (TH)}

Hardness of groundwater primarily results due to excessive concentration of divalent cations like calcium and magnesium in water. These ions enter a water supply by leaching from minerals within an aquifer. High levels of hard-water ions such as $\mathrm{Ca}^{2+}$ and $\mathrm{Mg}^{2+}$ can cause scaly deposits in plumbing, appliances, and boilers. These two ions also combine chemically with soap molecules, resulting in decreased cleansing action. Post-monsoon values vary between 146.268 and $1265.65 \mathrm{mg} / \mathrm{L}$ with an average of $469.33 \mathrm{mg} / \mathrm{L}$ (Table 2). Pre-monsoon values vary between 100.91 and $1435.35 \mathrm{mg} / \mathrm{L}$ with an average of 443.10 (Table 2). Premonsoon period water is much harder compared to postmonsoon period as evident from.

\section{Piper's diagram}

The suitability of water for drinking purpose is determined from Piper (1944) trilinear diagram (Fig. 12). It is the graphical representation of chemistry of water samples. The cations and anions are represented by separate ternary plots. The two ternary plots are then extrapolated onto the diamond diagram. Piper diagram can predict the water type in three ways-bicarbonate type, sulphate type and chloride type. The bicarbonate type is considered suitable for both drinking and agricultural purpose. Sulphate type is unsuitable for irrigation. In post monsoon session, almost $85 \%$ of water samples fall in bicarbonate or fresh water zone and only $15 \%$ of the samples fall in sulphate rich zone, whereas in pre monsoon period, almost $75 \%$ of the samples fall in fresh or bicarbonate water zone

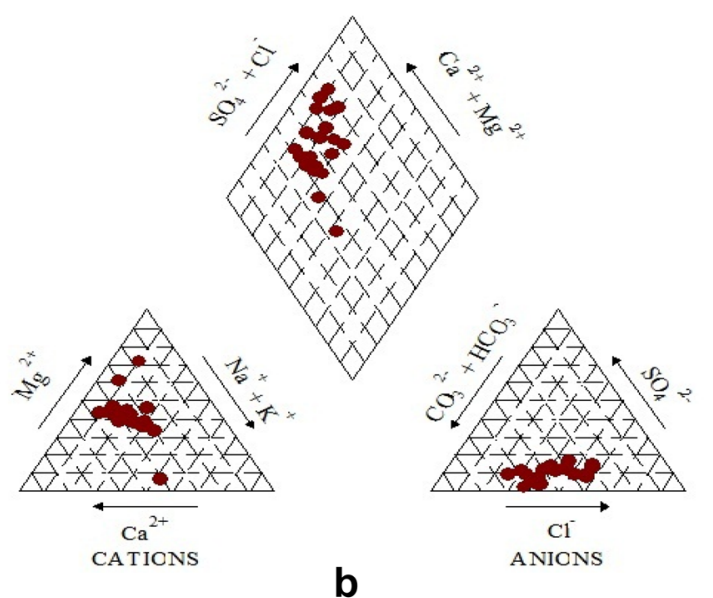


and only $25 \%$ of the samples fall in sulphate water zone in the study area.

\section{Water quality indices}

To get proper and effective information about the quality of water for us, the most constructive way is WQI. So, this parameter has a great significance for assessment and management of water. WQI may be defined as a rating reflecting the composite influence of a number of water quality parameters on the overall quality of water. Converting the water quality data to information for public is the major issue of WQI parameter. WQI is the based on some important parameters viz., $\mathrm{pH}$, electrical conductivity, total dissolved solids, calcium, magnesium, chloride, sulphate, bicarbonate, fluoride, iron, sodium, total alkalinity, total hardness, which can provide simple indicator of water quality to give a general idea of the viable problems with water in particular region.

For computing WQI three steps are followed (Ramakrishnaiah et al. 2009). In the first step, each of the 13 parameters has been assigned a weight $\left(w_{i}\right)$ according to its relative importance in the overall quality of water for drinking purposes (Table 6). Due to its major importance the maximum weight of 5 has been given to the parameter $\mathrm{pH}$, sulphate, fluoride, and iron in water quality assessment. As magnesium by itself may not be harmful, it is given the minimum weight of 1 .

In the second step, the relative weight $\left(W_{\mathrm{i}}\right)$ is computed from $t$ he following equation:

$W_{i}=\frac{w_{i}}{\sum_{i=1}^{n} w_{i}}$ where $W_{i}$ is the relative weight, $w_{i}$ is the weight of each parameter and $n$ is the number of parameters. Calculated relative weight $\left(W_{i}\right)$ values of each parameter are also given in Table 6.

In the third step, a quality rating scale $\left(q_{i}\right)$ for each parameter is assigned by dividing its concentration in each water sample by its respective standard according to the guidelines laid down in the BIS and the result multiplied by 100 :

$q_{i}=\left(C_{i} / S_{i}\right) \times 100$,

where $q_{i}$ is the quality rating, $C_{i}$ is the concentration of each chemical parameter in each water sample in $\mathrm{mg} / \mathrm{L}$, and $S_{i}$ is the drinking water standard for each chemical parameter in $\mathrm{mg} / \mathrm{L}$ according to the guidelines of the WHO (2011).

For computing the WQI, the SI is first determined for each chemical parameter. It is used to determine the WQI as per the following equation.

$\mathrm{SI}_{i}=W_{i} \times q_{i}$

$\mathrm{WQI}=\Sigma \mathrm{SI}_{i}$;

$\mathrm{SI}_{i}$ is the subindex of $i$ th parameter; $q_{i}$ is the rating based on concentration of $i$ th parameter and $n$ is the number of parameters. The computed WQI values are classified into five types, "excellent water" to "water, unsuitable for drinking".

WQI has been calculated using the standards of drinking water quality recommended by the World Health Organization (WHO) (2011), Bureau of Indian standards (BIS) (2012) and Indian Council of Medical Research (ICMR) (1975).

According to WQI classification, $45 \%$ fall in good water zones, $50 \%$ of the samples fall in poor water zones and $5 \%$ water samples fall in very poor water zones in post monsoon period, while in pre monsoon $40 \%$ samples
Table 6 Relative weight of chemical parameters for WQI index

\begin{tabular}{lllll}
\hline Parameters & \multicolumn{2}{l}{ Drinking water standards } & Weight $\left(w_{i}\right)$ & Relative weight $\left(W_{i}\right)$ \\
\cline { 2 - 3 } & WHO (1984) & ICMR $(1975)$ & & \\
\hline pH & $6.5-9.2$ & $6.5-8.5$ & 5 & 0.11363 \\
Electrical conductivity & 300 & - & 2 & 0.04545 \\
Total dissolved solids & 500 & $500-1500$ & 4 & 0.09090 \\
Calcium & 75 & 75 & 2 & 0.04545 \\
Magnesium & 50 & 50 & 2 & 0.04545 \\
Chloride & 200 & 250 & 3 & 0.06818 \\
Sulphate & 200 & 200 & 5 & 0.11363 \\
Bicarbonate & & & 3 & 0.06818 \\
Fluoride & $1.0-1.5$ & 1.0 & 5 & 0.11363 \\
Sodium & & & 3 & 0.06818 \\
Iron & & - & 5 & 0.11363 \\
Total alkalinity & - & 300 & 2 & 0.04545 \\
Total hardness & - & & 3 & 0.06818 \\
& & & $\sum w_{i}=44$ & $\sum W_{i}=1$ \\
\hline
\end{tabular}


fall in good water zones, $45 \%$ fall in poor water zones, $10 \%$ fall in very poor water zones and $5 \%$ fall in unsuitable for drinking zones (Table 5). The high value of WQI at these stations has been found to be mainly from the higher values of iron, total dissolved solids, hardness, fluorides, bicarbonate in the groundwater. The pie charts presented in Fig. 13 depict the categorization of groundwater samples according to WQI classes for post monsoon and pre monsoon sessions, respectively.

\section{Gibb's diagram}

The relationship of chemical component of water from their respective aquifer dispositions is properly justified by Gibb's diagram (1970). This diagram helps us to understand the genesis of groundwater. The chemical data of groundwater sample points of the studied area are plotted in Gibbs's diagram. Figure 14 represents the Gibb's diagrams of the post monsoon and pre monsoon session, respectively. It is noticed that all samples of both sessions fall in rock water dominance category.

\section{Scholler diagram}

Scholler (1977) diagram is a graphical method for drinking water quality classification. The diagram is plotted by the most important water-soluble salts including all major cations and anions as well as total hardness and total dissolved solids to classify the drinking water quality (Sayad et al. 2011). In this diagram (Fig. 15), water samples are divided in three zones namely good, acceptable and unsuitable zones according to desirable and permissible limits of the parameter (WHO 2011) for drinking water. Most of the samples fall in good and acceptable zones in both post- and pre-monsoon, respectively.
Fig. 13 Categorisation of groundwater according to WQI. a Post monsoon, b pre monsoon

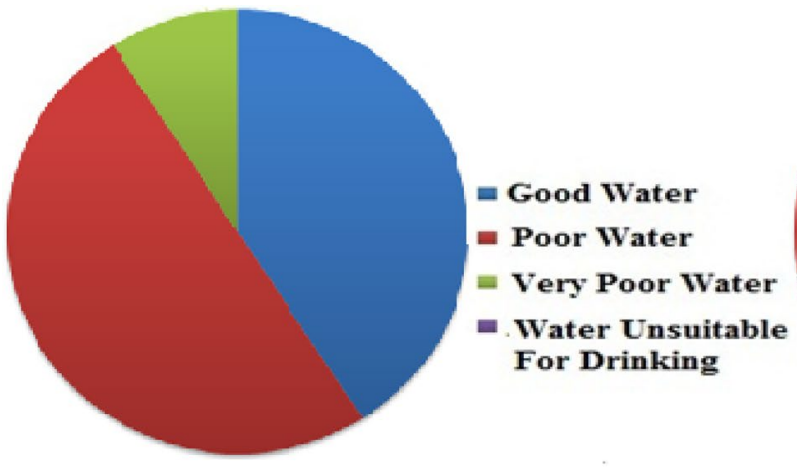

a

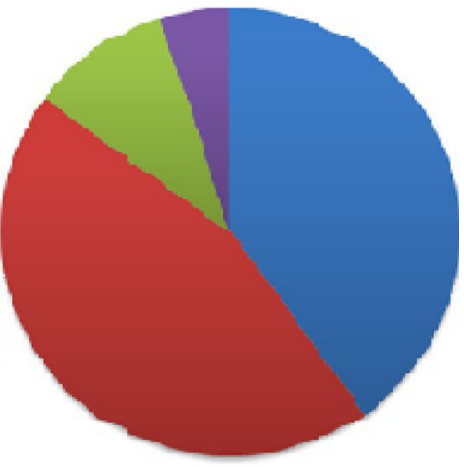

b
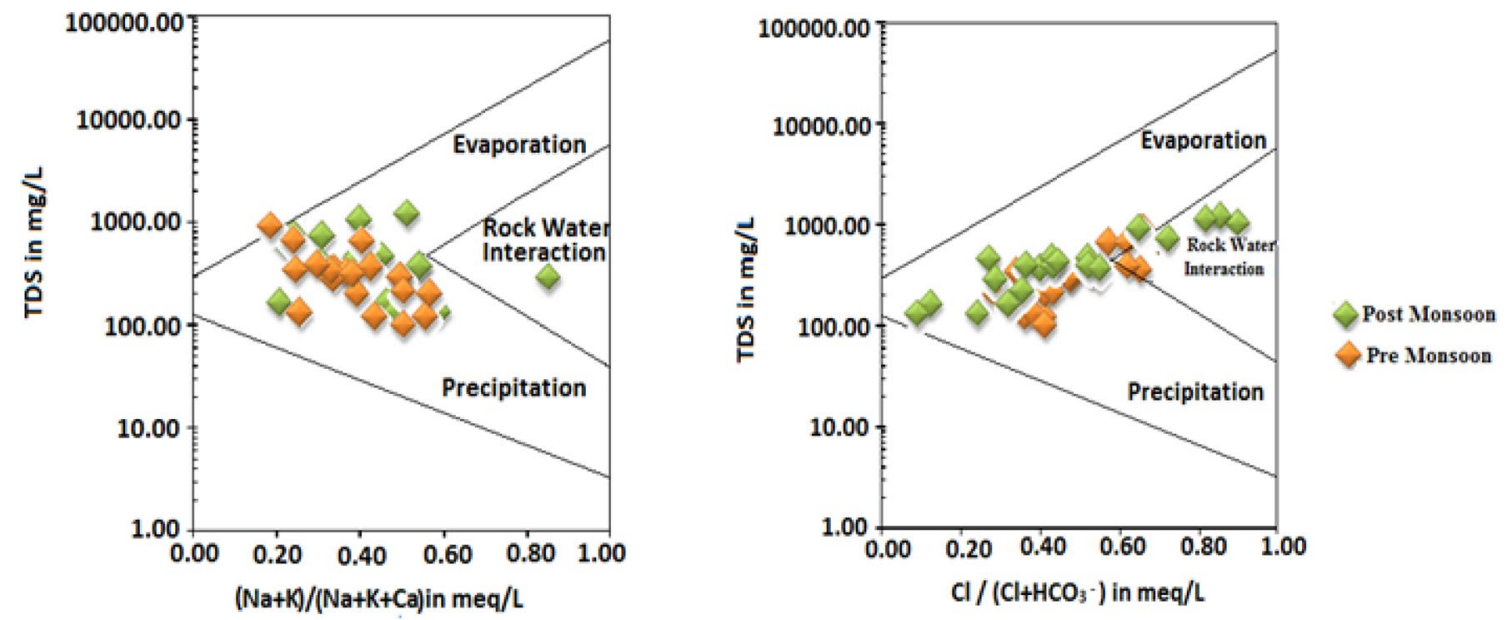

Fig. 14 Gibb's diagram 
Fig. 15 Scholler diagram (a post monsoon, b pre monsoon)
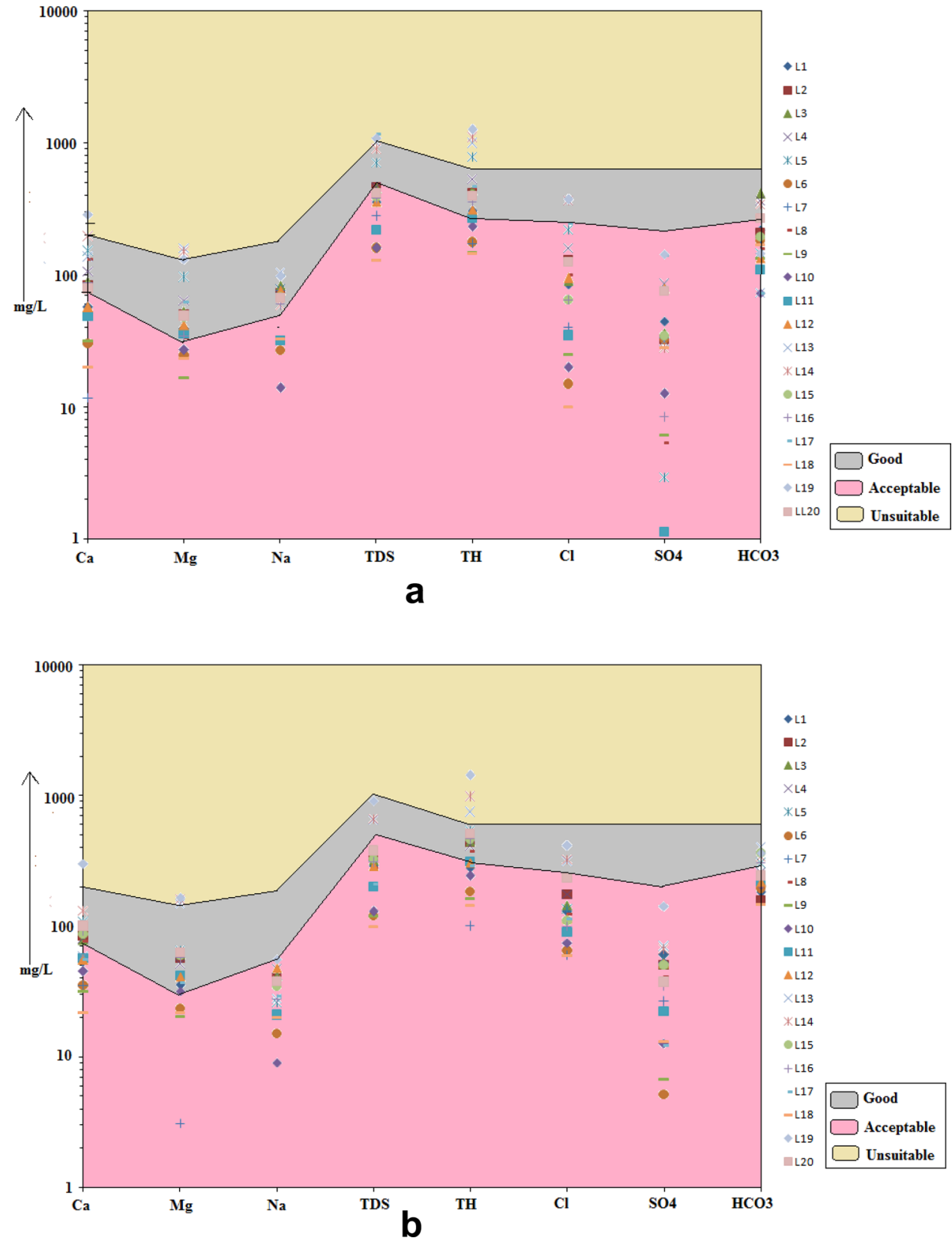

\section{Conclusions}

In the study area, altogether twenty (20) nos. of bore wells were marked and monitored for having idea of water level altitude and water quality in post monsoon and pre-monsoon. Water levels had fallen between post-monsoon and pre-monsoon field visit. The groundwater quality reveals that $\mathrm{pH}, \mathrm{EC}$ and TDS values of collected water samples were safe for drinking and irrigation purposes, as because they are not causing any health hazards. Other elements such as calcium, magnesium, sodium, chloride, carbonate, bicarbonate, sulphate, and fluoride in maximum places (80-90\%) are within allowable limits. But some places are having higher concentration which is beyond the allowable limits. But Iron $(\mathrm{Fe})$ content is very much higher from the allowable limits in maximum places $(80-90 \%)$ in this area. Fluoride concentration in the study are has been found to be a localized phenomenon as excess fluoride $(>1.5 \mathrm{mg} / \mathrm{L})$ was reported in two out of twenty locations. Assessment of the groundwater suitability for irrigation and drinking was one of the major objectives of this study because this study area chosen has a rural set-up where agriculture is the main occupation of the residents and piped water distribution systems providing potable water for cooking and drinking have not yet been set up. From piper's diagram, it can be stated that water samples of most of the area of the 
block having fresh water and some area having sulphate rich water throughout the year, most of the places of this block are suitable for drinking purposes. Calculation of water quality indices like SAR, SSP, MAR, RSC, PI, and $\mathrm{KR}$ were done to determine suitability of the groundwater. From the derived parameters study SAR value is excellent in all samples during the both sessions, so the water is suitable for irrigation use. According to Wilcox (1955) diagram, SSP values of pre-monsoon and post-monsoon water samples are indicating that water samples fall in excellent to good and good to permissible zones. According to the rest of the irrigational suitability parameters calculated, the ground water in the study area is found to be well suited in some areas and moderately suitable in some other. From WQI calculation, it can also be stated that during post-monsoon period, $45 \%$ samples fall in 'good' water zones, $50 \%$ samples fall in 'poor' water zones and $5 \%$ water samples fall in 'very poor' water zones. The number reduces to 40 and $45 \%$, respectively, for 'good' and 'poor' water zones while $10 \%$ of the water fall in 'very poor' and 5\% fall in 'unfit' for drinking purposes. From Gibb's diagram, it is observed that the all samples are distributed to central rock dominance category. From Scholler diagram, it is noticed that water of the most of the places of the study area has met the drinking water suitability criteria. So, it can be stated that the chemistry of groundwater is mainly controlled by the interaction existing between the litho units and the percolating water into the subsurface domain. From all of the above results it can be concluded the groundwater quality and its suitability both for domestic and irrigation purposes of this study area, can be termed as good to moderate with a few exceptions which have been encountered on a local scale.

Acknowledgements The author (A. Kundu) received financial support for doing this work from DST, Govt. of India, New Delhi through her DST Inspire Fellowship. She gratefully acknowledges this support. The corresponding author (S. K. Nag) expresses his gratitude to the Department of Geological Sciences, Jadavpur University for receiving financial support to carry out the field work from CAS-Phase VI of the department.

Open Access This article is distributed under the terms of the Creative Commons Attribution 4.0 International License (http://creativeco mmons.org/licenses/by/4.0/), which permits unrestricted use, distribution, and reproduction in any medium, provided you give appropriate credit to the original author(s) and the source, provide a link to the Creative Commons license, and indicate if changes were made.

\section{References}

Acheampong SY, Hess JW (1998) Hydrogeologic and hydrochemical framework of the shallow groundwater system in the southern Voltaian Sedimentary Basin, Ghana. J Hydrogeol 6(4):527-537
Afzali A, Shahedi K, Roshan MHN, Solaimani K, Vahabzadeh G (2014) Groundwater quality assessment in Haraz Alluvial fan, Iran. Int J Sci Res Environ Sci 2(10):346-360

Aghazadeh N, Mogaddam AA (2010) Assessment of groundwater quality and its suitability for drinking and agricultural uses in the Oshnavieh area, Northwest of Iran. J Environ Prot 1(1):30-40

Al-Futaisi A, Rajmohan N, Al-Touqi S, (2007) Groundwater quality monitoring in and around Barka dumping site, Sultanate of Oman. In: Proceedings of second IASTED WRM conference

American Public Health Association (APHA) (1995) Standard methods for the examination of water and wastewater, 19th edn. American Public Health Association, Washington DC

BIS (Bureau of Indian standards) (2012), Indian standard, Drinking Water-Specification, Second Revision, IS 10500: 2012, ICS 13.060.20

Brindha K, Elango L (2012) Impact of tanning industries on groundwater quality near a metropolitan city in India. Water Resour Manag 17(2012):47-1761

Doneen LD (1964) Water quality for agriculture. Department of Irrigation, University of California, Davis

Foster S, Chilton J, Moench M, Cardy F, Schiffer M (2000) Groundwater in rural development, World Bank technical paper, 463

Garrels RM, Mackenzie FT (1967) Origin of the chemical compositions of some springs and lakes. In: Stumm W (ed) Equilibrium concepts in natural water systems, advances in chemistry. American Chemical Society, Washington, DC

Gibbs RJ (1970) Mechanisms controlling world water chemistry. Science (New York, NY) 170:1088-1090

Goel PK (2000) Water pollution-causes, effects and control. New Age Int. (P) Ltd., New Delhi

Hossein MT (2004) Hydrochemical evaluation of groundwater in the Blue Nile Basin, eastern Sudan, using conventional and multivariate techniques. Hydrogeol J 12(2):144-158

Huh Y, Tsoi M, Zaitiser A, Edward JN (1998) The fluvial geochemistry of the river of Eastern Siberia. I. Tributaries of Lena River draining the sedimentation platform of the Siberia Craton. Geochim Cosmochim Acta 62:1657-1676

ICMR (1975) Manual of standards of quality of drinking water supplier, 2nd edn. Special report series no. 44. ICMR, New Delhi

Ishaku JM (2011) Assessment of groundwater quality index for JimetaYola area, Northestern Nigeria. J Geol Min Res 3(9):219-231

Jalali M (2006) Chemical characteristics of groundwater in parts of mountainous region, Alvand, Hamadan, Iran. Environ Geol 51:433-446

Kaka EA, Akiti TT, Nartey VK, Bam EPK, Adomako D (2011) Hydrochemistry and evaluation of groundwater suitability for irrigation and drinking purposes in the southeastern Volta river basin: manya krobo area, Ghana. Elixir Agric 39:4793-4807

Kelly WP (1976) Use of saline irrigation water. Soil Sci 95(4):355-391

MacDonald AM, Davies J, Dochartaigh BEO (2002) Simple methods for assessing groundwater resources in low permeability areas of Africa. Commissioned report CR/01/168N, British Geological Survey, UK

Mercado A (1985) Use of hydrochemical pattern in carbonate, sand and sandstone aquifers to identify intrusion and flushing saline water. Groundwater 23(5):635-645

Nag SK (2014) Evaluation of hydrochemical parameters and quality assessment of the groundwater in Gangajalghati Block, Bankura District, West Bengal, India. Arab J Sci Eng 39(7):5715-5727

Nag SK, Das Shreya (2017) Assessment of groundwater quality from Bankura I and II blocks, Bankura District, West Bengal, India. Appl Water Sci. https://doi.org/10.1007/s13201-017-0530-8

Nag SK, Ghosh P (2013) Variation in groundwater levels and water quality in Chhatna block, Bankura district, west Bengal- A GIS approach. J Geol Soc India 81(2):261-280

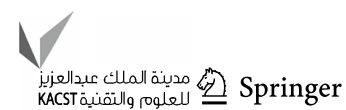


Nag SK, Lahiri A (2012) Hydrochemical characteristics of groundwater for domestic and irrigation purposes in Dwarakeswar watershed area, India. Am J Clim Change 1(4):217-230

Nag SK, Suchetana B (2016) Groundwater quality and its suitability for irrigation and domestic purposes: a study in rajnagar block, Birbhum district, West Bengal India. J Earth Sci Clim Change 7:337. https://doi.org/10.4172/2157-7617.1000337

Naseem S, Ahmed P, Shamim SS, Bashir E (2011) Geochemistry of sulphate-bearing water of Akra Kaur Dam, Gwadar, Balochistan, Pakistan and its assessment for drinking and irrigation purposes. Environ Earth Sci 66:1831-1838

Obiefuna GI, Sheriff A (2011) Assessment of shallow ground water quality of Pindiga Gombe area, Yola area, NE, Nigeria for irrigation and domestic purposes. Res J Environ Earth Sci 3(2):131-141

Olayinka AI, Abimbola AF, Isibor RA, Rafiu AB (1999) A geoelectric hydrochemical investigation of shallow groundwater occurrence in Ibadan, South-Western Nigeria. Environ Geol 37(1-2):31-37

Pandian K, Sankar K (2007) Hydrogeochemistry and groundwater quality in the Vaippar River basin, Tamil Nadu. J Geol Soc India 69:970-982

Park K (1997) Park's textbook of preventive and social medicine. Banarsidas Bharat Publishers, Jabalpur

Pichaiah S, Kumar SGR, Srinivasanmoorthy K, Sarma VS (2013) Hydrochemical characterization and quality assessment of groundwater in TirupurTaluk, Tamil Nadu, India: emphasis or irrigation utility. J Acad Ind Res 1(12):805-812

Piper AM (1944) A graphic procedure in the geochemical interpretation of water-analyses. Trans Am Geol Surv 475-B:186-188

Pritchard M, Mkandawire T, O'Neill JG (2008) Assessment of groundwater quality in shallow wells within the southern districts of Malawi. Phys Chem Earth 33:812-823

Raghunath HM (1987) Groundwater, 2nd edn. Wiley eastern limited, New Delhi, India, pp 344-369

Rajankar PN, Gulhane SR, Tambekar DH, Ramteke DS, Wate SR (2009) Water quality assessment of groundwater resources in Nagpur Region (India) based on WQI. E J Chem 6(3):905-908

Raji BA, Alagbe SA (1997) Hydrochemical facies in parts of the Nigerian basement complex. Environ Geol 29(1-2):46-49

Raju NJ (2007) Hydrogeochemical parameters for assessment of groundwater quality in the upper Gunjanaeru River Basin, Cuddapah District, Andhra Pradesh, South India. Environ Geol 52(2007):1067-1074

Ramakrishnaiah CR, Sadashivaiah C, Ranganna G (2009) Assessment of water quality index for ground water in Tumkur Taluk, Karnataka state, India. E J Chem 6(2):523-530

Rao YS, Reddy TVK, Nayudu PT (1997) Ground-water quality in the Niva River basin, Chittoor district, Andhra Pradesh, India. Environ Geol 31(1):56-63

Reddi KR, Jayaraju N, Suriyakumar I, Sreenivas K (1993) Tidal fluctuation in relation to certain physico-chemical parameters in Swarnamukhi river estuary, East Coast of India. Indian J Mar Sci 22:223-234

Richards LA (1954) Diagnosis and improvement of saline and alkali soils; agric handbook, vol 60. USDA and IBH Publ. Coy Ltd., New Delhi, pp 98-99
Rivers CN, Hiscock KM, Feast NA, Barrett MH, Dennis PF (1996) Use of nitrogen isotopes to identify nitrogen contamination of the Sherwood sandstone aquifer beneath the city of Nottingham, UK. Hydrol J 4(1):90-102

Sayad N, Ditterich IRG, Pinto MHB, Wambier DS (2011) Concentraco de fluorem aguas minerais engarrafadas commercializadasno municipio de Ponta Grossa-PR. Rev Odontol UNESP 40:182-186

Schiavo MA, Havser S, Gusimano G, Gatto L (2006) Geochemical characterization of groundwater and sub-marine discharge in the southeastern Sicily. Cont Shelf Res 26(7):826-834

Scholler H (1977) Geochemistry of groundwater. Groundwater studies-an international guide for research and practice. UNESCO, Paris, pp 1-18

Shah T (2009) Taming the anarchy: groundwater governance in South Asia. Resources for the future, Washington DC and International Water Management Institute, Colombo

Subramani T, Elango L, Damodarasamy SR (2005) Groundwater quality and its suitability for drinking and agricultural use in Chithar River Basin, Tamil Nadu, India. Environ Geol 47(8):1099-1110

Tiwari RN (2011) Groundwater Quality Assessment of Mangawa area, Rewa District, Madhya Pradesh, India. Int J Earth Sci Eng 04(06):1000-1009

Todd DK (1980) Groundwater hydrology, 2nd edn. Wiley, New York, p 535

Tripathy JK, Panigrahy RC (1999) Hydrochemical assessment of groundwater in parts of south coastal Orissa. India. J Environ Hydrol 7(paper 3):1-9

US Salinity Lab (1954) Saline and alkali soils—diagnosis and improvement of US Salinity Laboratory. Agriculture Hand Book No. 60, Washington

Umar R, Khan MMA, Absar A (2006) Groundwater hydrochemistry of a sugarcane cultivation belt in parts of Muzaffarnagar District, Uttar Pradesh, India. Environ Geol 49(7):999-1008

Vasanthavigar M, Srinivasamoorthy K, Vijayaragavan K, Rajiv Ganthi R, Chidambaram S, Sarama VS, Anandhan P, Manivannan R, Vasudevan S (2010) Application of water quality index for groundwater quality assessment: Thirumanimuttar sub-basin, Tamilnadu, India. Environ Monitor Assess 171(1-4):595-609

WHO (1984) Guidelines for drinking-water quality, vol 1. Recommendations, vol 2. Health criteria and other supporting information. World Health Organization, Geneva

WHO (2011) Guideline for drinking water quality, 4th edn. World Health Organization, Geneva

Wilcox LV (1948) Classification and use of irrigation waters. U.S. Department of Agriculture, Washington, Circulation. No. 962

Wilcox LV (1955) Classification and use of irrigation waters, U.S.A. Salinity lab, Circulation. No. 969

Publisher's Note Springer Nature remains neutral with regard to jurisdictional claims in published maps and institutional affiliations. 